See discussions, stats, and author profiles for this publication at: https://www.researchgate.net/publication/303360433

Project Suspensions and Failures in New Product Development: Returns for Entrepreneurial Firms in Co-Development Alliances: Project Suspensions and Failures in New Product Developm...

Article in Journal of Product Innovation Management · May 2016

DOI: $10.1111 /$ jpim.12322

3 authors:

Yansong Hu

The University of Warwick

7 PUBLICATIONS 61 CITATIONS

SEE PROFILE

Dorota Piaskowska

University College Dublin

16 PUBLICATIONS 52 CITATIONS

SEE PROFILE

Some of the authors of this publication are also working on these related projects:

Peter McNamara

National University of Ireland, Maynooth

48 PUBLICATIONS 330 CITATIONS

SEE PROFILE

Project Managing Academic Careers and Performance View project

Biotech and Connected Health Cases View project 


\title{
Project Suspensions and Failures in New Product Development: Returns for Entrepreneurial Firms in Co-Development Alliances
}

\author{
Yansong $\mathrm{Hu}$, Peter McNamara, and Dorota Piaskowska
}

Entrepreneurial biotech and large pharmaceutical firms often form alliances to co-develop new products. Yet, new product development (NPD) is fraught with challenges that often result in project suspensions and failures. Considering this, how can firms increase the chances that their co-development alliances will create value? To answer this question, the authors build on insights from signaling theory to argue that prior project suspensions provide positive signals leading to an increase in value creation, while project failures have the opposite effect. In addition, drawing on insights from temporal construal theory, this research predicts that the strength of these effects is contingent on the stage along the exploration-exploitation continuum at which the alliance is formed. The authors undertook event study analyses of 248 alliances formed by 104 biotechnology firms from the United States and Europe listed on eight stock exchanges over an 8-year period between 1996 and 2003. The results confirm that prior NPD project suspensions have a stronger value creation effect (or prior failures have a weaker value destruction effect) in the case of exploration alliances in the upstream of NPD processes than in the case of moderate-scale exploitation alliances in the downstream of NPD. This study is among the first to examine how both prior NPD project suspensions and failures of firms affect the abnormal returns achieved from codevelopment alliances. This research therefore contributes to the innovation literature by honing a better understanding of setbacks and failures in NPD. Moreover, the findings contribute to the literature on strategic alliances by identifying new conditions under which firms can create or preserve value. This research also contributes to signaling theory by providing evidence of the moderation effect caused by the signaling environment. Finally, this study contributes to the entrepreneurial literature on value creation for entrepreneurial firms in alliances following adverse events.

\section{Practitioner Points}

- Managers should be aware that signaling suspensions and failures to investors can influence their expectations of future NPD performance and consequently impact shareholder value created through subsequent NPD alliances.

- Proactive portfolio management, including deprioritization of existing projects while allocating and re-allocating resources to active projects, can send out positive signals to investors to create better value in NPD alliances.

- For those firms planning to build a culture of tolerance toward failure, entering co-development alli-

Address correspondence to: Yansong Hu, Warwick Business School, University of Warwick, UK. E-mail: Yansong.hu@wbs.ac.uk. Tel: +00442476523915. ances may be more desirable at exploratory stages of the NPD process than later on.

\section{Introduction}

I $\mathrm{n}$ high-tech industries, entrepreneurial firms are a driving force for innovation. Yet, they may lack the critical resources and capabilities required to exploit their inventions. These firms often form codevelopment alliances with large, incumbent firms to access complementary assets and capabilities that are necessary to develop and commercialize inventions in their NPD process (Fang, 2008; Rothaermel and Deeds, 2004; Wuyts, Dutta, and Stremersch, 2004). Prior research has shown that such alliances enhance an entrepreneurial firm's product innovation (George, Zahra, and Wood, 2002; Kelley and Rice, 2002), and provide opportunities for inter-organizational learning 
that boost the firm's commercialization abilities (Grant and Baden-Fuller, 2004; Holmqvist, 2003).

At the same time, prior research has recognized that both alliances and NPD projects are difficult tasks for managers (Emden, Calantone, and Droge, 2006; Henard and Szymanski, 2001; Montoya-Weiss and Calantone, 1994). Alliances are fraught with problems, ranging from partner selection (Emden et al., 2006) to how best to manage the alliance to create value for the partners (Yang, Zheng, and Zhao, 2014). In particular, entrepreneurial firms are difficult to evaluate for investors and alliance partners alike because they lack a performance track record or even previous revenues (Shane and Stuart, 2002). Therefore, in evaluating an entrepreneurial firm, investors have to rely on observable attributes or "signals" to assess the unobserved quality of a firm's technology and NPD projects (Stuart, Hoang, and Hybel, 1999), such as a prestigious board of directors (Certo, Daily, and Dalton, 2001; Spence, 1973). Furthermore, as many as three out of four NPD projects fail (Cooper, 1990), and setbacks and dead ends are commonplace (Van de Ven, Polley, Garud, and Venkataraman, 1999). These may arise due to a range of issues associated with the NPD process, firm strategy, culture, resources, and commitment

\section{BIOGRAPHICAL SKETCHES}

Dr. Yansong Hu is an associate professor of marketing at Warwick Business School, University of Warwick. His research focuses on product innovations and diffusion, and specifically on the processes and outcomes of innovation, including how social networks influence new product development and adoption. His research output has appeared in marketing and management journals, including Marketing Science, Journal of Services Marketing, Technovation, among others.

Professor Peter McNamara is professor of management and head of the School of Business at Maynooth University. His research focuses on the processes and performance consequences of collaboration and innovation. His research has been published in management journals including Journal of Management, Research Policy, Academy of Management Education and Learning, Journal of Business Venturing, British Journal of Management, Long Range Planning, Technovation, among others. He is currently the Vice Chairperson of the Academy of Management's MED division.

Dr. Dorota Piaskowska is a tenured faculty in management at University College Dublin, Ireland. Dorota is a board member of European International Business Academy. She has previously served as the academic director for UCD programs in Singapore and Ireland and held leadership roles at the Academy of Management. She received her Ph.D. from Tilburg University in the Netherlands. She researches individual, team-level, and organizational learning and other factors influencing complex corporate development activities such as alliances and acquisitions. Her research has appeared in British Journal of Management and European Management Review and has been featured in The Financial Times and Irish Independent, among others.
(Barczak, Griffin, and Kahn, 2009; see, e.g., Henard and Szymanski, 2001, and Montoya-Weiss and Calantone, 1994, for reviews). Managers may thus ask a key question: bearing in mind the inherent difficulties of co-developing new products in alliances, how can entrepreneurial firms manage the tasks involved in creating value?

Prior research has indicated that entrepreneurial firms' ability to weather adverse events such as NPD withdrawals depends on the stock of projects in the NPD pipeline, alliance partners, and the firms' ability to work with them (Baron, 2000; De Carolis, Yang, Deeds, and Nelling, 2009; Hoang and Rothaermel, 2005). While this last factor has been well documented in prior research, comparatively little is known about the impact of past NPD setbacks on entrepreneurial firms' ability to create value with new co-development alliances. Yet, the experience of NPD setbacks is a commonplace aspect of the innovation journey for many entrepreneurial firms. During their NPD processes, entrepreneurial firms deal with projects which fail to pass screening gates and are abandoned, as well as ones which are put on hold if the timing is not right or there are other, better projects that require the same resources (Cooper, 2008). While some projects may be pursued at a later date when the prioritization and timing issues are resolved (Cooper and Edgett, 2012) and may help to improve new product quality in the end (McNally, Akdeniz, and Calantone, 2011), NPD setbacks are costly (De Carolis et al., 2009) and may negatively impact firm performance (Lokshin, Hagedoorn, and Letterie, 2011). This indicates that different types of NPD setbacks have both positive and negative performance consequences and signal different abilities (or a lack of them) on the part of entrepreneurial firms. Therefore, prior NPD setbacks can be important signals for investors when firms enter into co-development alliances.

In this article, the authors consider the role played by prior NPD setbacks in value creation through new co-development alliances by (1) differentiating between positive signals from prior project suspensions and negative signals from prior project failures, and (2) considering the strength of these effects. This depends on the stage along the exploration-exploitation continuum at which the alliance is formed, where exploration is described as activities related to experimentation with new alternatives, which yields distant and uncertain returns, and exploitation involves the refinement and extension of existing technologies, 
which yields returns that are closer and more predictable (March, 1991; Rothaermel and Deeds, 2004).

This research relies on signaling theory as a theoretical framework (Spence, 1973, 2002). A particular challenge for investors seeking to assess the quality of entrepreneurial firms is information asymmetry, which is a serious issue when establishing new alliances. It is argued that an entrepreneurial firm's prior project suspensions provide a positive signal to investors and partners that it has robust and marketable ideas which could be capitalized on with a new product codevelopment alliance, leading to increased value creation. In contrast, entrepreneurial firms' prior project failures are negative signals reflecting their issues in the technology portfolios; they may reduce these firms' attractiveness and raise alliance costs for prospective partners, thus exerting a negative effect on the firms' ability to create value through such alliances.

Prior literature has suggested that the interorganizational signaling effects can be moderated by the influence of the task environment (Sanders and Boivie, 2004). Therefore, this study further argues that they are contingent on the signaling environment (Connelly, Certo, Ireland, and Reutzel, 2011) of the alliance announcement, and in particular the stage of NPD (along the exploration-exploitation continuum) at which the alliances are formed. This continuum starts with upstream exploration activities, followed by downstream exploitation activities (including moderate-scale and large-scale exploitations). By drawing insights from construal theory (Trope and Liberman, 2003), this research hypothesizes that, for the signals of prior project suspensions and failures, exploration alliances in the upstream of NPD add more to the positive value creation of suspensions (or do more to counter the value damage of failures) than moderate-scale exploitation alliances in the downstream of NPD. According to construal theory, when investors evaluate the value of a firm in an exploitation alliance pursuing downstream NPD activities, they tend to focus on how likely the future NPD is to succeed. For moderate-scale, downstream exploitation alliances, there is a very high failure rate before projects can reach final commercialization, suggesting a high level of uncertainty and risk (Heide and John, 1990); investors thus tend to see prior project suspensions and failures as being of less value at this stage. In contrast, judging an entrepreneurial firm in an NPD alliance in the upstream development stages of exploration, investors are less likely to focus on the feasibility of future NPD success because the finalization of the development process and the product's market introduction are distant in time. Instead, they will focus more on the desirability of the exploration alliance (the value of a successful new product launch), and their perception of its value will thus be higher. These tendencies have been long described in literature on the behavior of future optimism, where people tend to harbor more positive expectations of distant outcomes (Mitchell, Thompson, Peterson, and Cronc, 1997; Trope and Liberman, 2003).

To test their hypotheses, the researchers collected data on 248 NPD alliances formed by 104 biopharmaceutical firms over an 8-year period between 1996 and 2003 in eight stock exchanges in the United States and Europe. This research adopted the alliance formation event as the unit of analysis, and used a standard event study methodology to capture value creation on new alliance formation by measuring abnormal stock market returns around the time of alliance announcement (e.g., Gulati and Wang, 2003; Swaminathan and Moorman, 2009). The analyses support the hypotheses.

This article seeks to make several contributions to the literature. First, this study is among the first to examine how both prior NPD suspensions and failures of firms affect the abnormal returns achieved from codevelopment alliances. The findings contribute to the innovation literature by honing a better understanding of setbacks and failures in NPD (Barczak, 2014). NPD is perceived to be "among the essential processes for success, survival and renewal of organizations, particularly for firms in either fast-paced or competitive markets" (Brown and Eisenhardt, 1995, p. 344). It is commonly acknowledged that NPD suspensions and failures are frequent among high-technology firms. Few extant studies have explored the issue of suspensions and failures, and even fewer have related suspensions and failures to the variance in performance outcomes. In this study, the researchers unpack the impact of prior suspensions and failures, and provide a richer view of their different effects, which may suggest mechanisms for promoting or preventing effective learning and creating value (cf. Barczak, 2014).

Second, the findings also contribute to the literature on strategic alliances by identifying the conditions in which firms can create or preserve value (Merchant and Schendel, 2000). Recent research has looked into the different conditions of value creation in alliances, including different past experiences of alliances, such as general versus partner-specific experience (Gulati, Lavie, and Singh, 2009), the strategic fit and industry fit of the focal firm (Yamakawa, Yang, and Lin, 2011), and the size and type of partners in an alliance (Yang et al., 2014). This study contributes to this 
literature by highlighting the collective impact of project suspensions and failures on firms' financial performance in a critical innovation activity, namely codevelopment alliances.

Third, this research also contributes to signaling theory by providing evidence of the moderation effect caused by the signaling environment (Lester, Certo, Dalton, Dalton, and Cannella, 2006), which remains an understudied area in the application of signaling theory (Connelly et al., 2011). This study suggests that the strength of signaling effects of prior suspensions and failures is contingent on the changing signaling environment along the exploration-exploitation continuum on which the alliance is formed.

Finally, this study contributes to the entrepreneurial literature on value creation for entrepreneurial firms in alliances during adverse events (De Carolis et al., 2009). It is well understood that adverse events have a negative performance impact at the time of occurrence (De Carolis et al., 2009), and there is also evidence that failure experience can be learnt from, leading to longer-term success (McNamara and Baden-Fuller, 1999). This study adds to this literature by demonstrating the circumstances in which the past setbacks of entrepreneurial firms can create or reduce value long after the adverse effect has occurred.

\section{Literature Review}

\section{Project Suspension and Failure Defined}

Innovation processes are characterized by multiple temporal rhythms and experiences (Cooper, 2008; Garud, Tuertscher, and Van de Ven, 2013). This implies that the management of NPD projects is complex to the extent it requires temporal coordination (Cooper, Edgett, and Kleinshmidt, 1998, 1999). It is also complex because managers need to balance the sometimesconflicting tasks of maximizing expected economic returns, minimizing potential risk, and maintaining diversity in the NPD portfolio, all with limited resources (Blau, Pekny, Varma, and Bunch, 2004). In addition, uncertainty and constraints such as those resulting from organizational structure or insufficient resources and knowledge make NPD project management a challenging process, and managers need to monitor existing projects constantly with a view of accelerating some of them while killing, suspending, or deprioritizing others to allocate or re-allocate resources to active projects (Cooper et al., 1998, 1999).
To deal with such complexity, different temporal coordination mechanisms have been developed, including the stage-gate mechanism, in which "gates" are positioned at places along the product development process that are most beneficial to facilitating performance evaluation and enabling management to make "go/kill/hold/recycle" decisions on the project (Cooper, 1990, 2008). A project can fail when objective performance information indicates that the only rational option is to cancel the project prior to its completion because of technical failures or a violation of budgetary or time constraints (Cooper, 2003; Cooper and Kleinschmidt, 1990). Where the decision is less clearcut, a project may be suspended, that is to say effectively put on hold, for it potentially to continue at a later date when the resource, prioritization, timing, and technical issues have been resolved (Cooper and Edgett, 2012).

It follows from the literature reviewed above that there are two principal types of decision, which managers can take when a project needs to be stopped at any particular stage. First, the project can be "killed." Such project failure occurs when the project cannot satisfy the screening criteria required to proceed further and is evaluated as a poor investment (Cooper, 2003; Cooper and Edgett, 2012; Cooper and Kleinschmidt, 1990). Second, the project can be put on hold, or suspended. In contrast to project failures, suspended projects "pass" the screening gate (Cooper and Edgett, 2012, p. 53) but need to be paused for other reasons. Therefore, on their own, suspended projects can be good investments (Cooper, Edgett, and Kleinschmidt, 2002). In sum, the first critical difference between project suspensions and failures is whether they pass the screening criteria and are evaluated as having good investment potential, all else being equal.

The second difference between project failures and suspensions is that the possibility of restarting a failed project which has been killed is low, while a suspended project can be restarted more readily. A failed project is typically stopped permanently. In contrast, a typical reason why a project is suspended is because the timing is not right or there are other, better projects that require the same resources. Suspended projects may continue at a later date when the resource constraints and prioritization and timing issues have been resolved (Cooper and Edgett, 2012); once the resources become available, then, suspended projects can be reactivated.

The resources can be obtained internally or come from outside of the firm, in particular from a co- 
development alliance. When a project is not viable due to a lack of complementary assets (Brown, 1997), such assets can come from external sources such as customer ideas or alliances (Rothaermel and Deeds, 2004; von Hippel, 1978). Similarly, knowledge can be obtained both from within and outside firm boundaries (Ahuja, Lampert, and Tandon, 2008; Cohen and Levinthal, 1990; Katila and Ahuja, 2002). In particular, research has shown that external knowledge accessed from $R \& D$ alliance partners impacts NPD positively (Deeds and Hill, 1996; Rothaermel and Deeds, 2004).

Associated with resource availability are timing issues. For project suspensions, timing issues may be resolved at a later date, and the same applies to problems with resources. Although there is no specification on how long a project suspension may last (and technically a suspension can be put on hold permanently and therefore becomes a failure), the literature implies that suspension should be short term and temporary and may vary across different projects and industries (Cooper and Edgett, 2012; Cooper et al., 2002). Importantly, what is put on hold at one point in time may become viable later (Van de Ven et al., 1999). In sum, the ability to reactivate a project when timing issues are resolved and resources become available, possibly from a co-development alliance partner, distinguishes suspended projects from failed projects.

Because of the two differentiating features of project suspensions and failures, the former may signal to outsiders that the focal firm has positive and marketable ideas but lacks certain resources required to continue the projects. However, project failures may signal problems (Girotra, Terwiesch, and Ulrick, 2007).

\section{Signaling Theory}

Prior project suspensions and failures can be important signals when an NPD alliance is announced (Spence, 1973, 2002). In the high-tech industries, investors face significant risk when investing in entrepreneurial firms because of the high level of uncertainty affecting these firms. With their products still in the development stage, they typically do not have a track record of successful product launches and may not generate any revenues (Shane and Stuart, 2002). In addition, they have high technical and commercial failure rates (Aldrich and Fiol, 1994). At the same time, there are severe information asymmetries between entrepreneurial firms and investors because the firms possess more information about the quality of their technologies and NPD projects than outside investors do (Shane and Stuart, 2002). As a result, when evaluating an entrepreneurial firm, investors have to rely on observable attributes or "signals" (e.g., patent citations and outcomes of prior NPD projects) to assess the unobserved quality of the technology and NPD projects of the firm (Stuart et al., 1999). In this article, prior project suspensions and failures are conceptualized as useful "signals" for investors evaluating the value-creation potential of new co-development alliances in particular.

To this end, signaling theory suggests that information asymmetry problems are mitigated by signals conveying useful information (Spence, 1973, 2002). Signaling theory is frequently cited in the entrepreneurship literature (Lester et al., 2006), marketing literature (Kirmani and Rao, 2000), and NPD literature (Akdeniz, Calantone, and Voorhees, 2014). It describes the process by which the signaler (the entrepreneurial firm) sends a signal that is received by the receiver (potential investors and alliance partners) within a certain signaling environment (Busenitz, Fiet, and Moesel, 2005; Cohen and Dean, 2005). In this process, signals and the signaling environment determine the receiver's evaluation of the signaler's quality or value.

\section{Signal}

In the context of NPD alliances in drug discovery, entrepreneurial firms are difficult to evaluate for investors because they lack a performance track record or even revenues (Shane and Stuart, 2002). Therefore, such firms send signals to indicate their unobservable quality and gain legitimacy (Rao, Chandy, and Prabhu, 2008). Such signals include having prestigious boards of directors (Certo et al., 2001) or top managers (Lester et al., 2006), maintaining resources such as technology and patents (Katila and Ahuja, 2002; Levitas and McFadyen, 2009), and engaging in alliances and NPD projects (Hoenig and Henkel, 2015; Rao, Lu, and Ruekert, 1999). In line with signaling theory, all of these can serve as signals as they have the following features, namely, they are differentially costly to obtain for ventures of different quality; are based on distinctive, observable, and alterable characteristics; and are irreversible in the short term (Janney and Folta, 2003; Ozcan and Overby, 2008; Spence, 1973).

Following the prior literature (e.g., Certo et al., 2001; Rao et al., 2008), two categories of signals used 


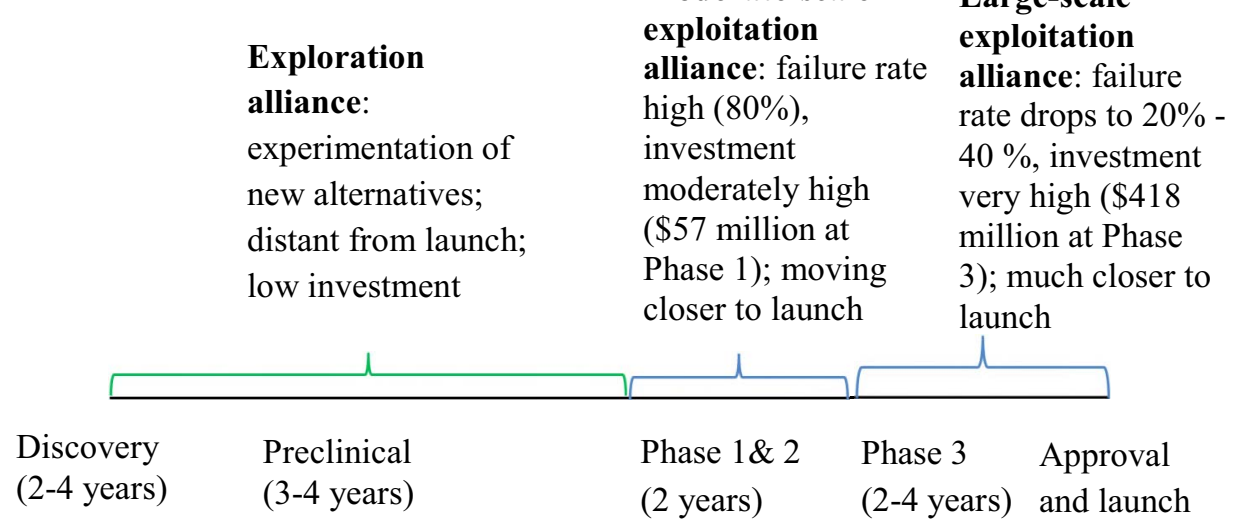

Figure 1. Drug Discovery: Time Frame and Varying Investments and Risks

Source: Adapted from FDA (1999), and Chandy, Hopstaken, Narasimhan, and Prabhu (2006).

by entrepreneurial firms entering into NPD alliances can be identified: internal signals, including historical, scientific, market, and locational aspects of the firm, and external signals, including alliances and partners (Gulati and Higgins, 2003; Park and Mezias, 2005).

The most readily available signals are arguably historical ones. Historical signals convey information about the entrepreneurial firm's past performance and technological capability and, by inference, its future prospects. For example, the literature on technological path dependencies suggests that past technology may lock a firm in or out of certain technological trajectories (e.g., Dosi, 1988; Schilling, 1998). In a similar vein, Helfat and Raubitschek (2000) argue that a firm's product history limits its choices for future product structures. When the firm forms an NPD alliance, its past technologies and products signal the alliance's (and its products') chances of success. Therefore, historical signals, such as past performance, quality of patents, which pharmaceutical firms use to appraise the prospects of biotechnology firms (Rothaermel, 2002), and prior NPD project suspensions and failures, gain a new meaning for investors when the entrepreneurial firm announces a new co-development alliance. These are important signals of the future value of the entrepreneurial firms.

Other internal signals include scientific, market, and locational signals. Scientific signals convey information that the entrepreneurial firm has the scientific knowledge and capability needed to operate in the industry successfully. An entrepreneurial firm may send this signal by, for example, recruiting eminent scientists to serve on its board (Certo et al., 2001).

Market signals may convey information that the entrepreneurial firm has NPD projects targeting a siza- ble market, which has the potential to deliver value to its investors (Rao et al., 2008).

Finally, locational signals convey information that the firm may derive a differential advantage from its geographic location (Porter, 1998).

External signals, meanwhile, include alliances and partners (Gulati and Higgins, 2003; Park and Mezias, 2005). NPD alliances have been argued to serve as signals of the quality of an entrepreneurial firm's technology (Baum and Silverman, 2004; Pisano, 1990) and to legitimize the firm (Rao et al., 2008). In addition, alliance partners are pathways for the exchange of resources and signals that convey recognition and legitimation to outsiders (Stuart, 2000).

\section{Signaling Environment}

Apart from their characteristics, the effectiveness of internal and external signals also depends on the environment in which the signals are received (Ilmola and Kuusi, 2006). This signaling environment can affect the extent to which signals reduce information asymmetry and how receivers notice and interpret the signals (Lester et al., 2006). In particular, during interorganizational signaling, one might expect different effects to arise from the influence of the task environment (Sanders and Boivie, 2004).

As illustrated in Figure 1, in the context of codevelopment alliances in the pharmaceutical industry in particular, the signaling environment has a number of features which may vary at different stages of the NPD process, including the major activities involved, the levels of investment, and related risks and failure rates. In 
the pharmaceutical industry, the NPD process is costly and has a long time frame and a low success rate. Taking a drug to market can involve a capitalized cost of over \$800 million (DiMasi, Hansen, and Grabowski, 2003) and take more than 13 years (Kellogg and Charnes, 2000). These features affect how investors interpret the signals they receive from the entrepreneurial firms at different stages in the drug NPD process (Trope and Liberman, 2003).

To describe the different stages of the NPD process for drugs, the prior literature has distinguished between the exploration and exploitation phases (e.g., Rothaermel and Deeds, 2004). Co-development alliances formed at the initial, exploration stage focus on upstream activities in the value chain, such as basic research, drug discovery, and development. Alliances formed at later stages focus on exploitation, that is to say downstream activities, including clinical trials, regulatory processes, and launch. Within this second type of alliances, this study further distinguishes between alliances focusing on moderatescale and large-scale downstream activities, where alliances focusing on Phases 1 and 2 clinical trials are classified as "moderate-scale exploitation alliances" and those focusing on Phase 3 clinical trials, approval, and launch are termed "large-scale exploitation alliances" (Urbig, Bürger, Patzelt, and Schweizer, 2013). This distinction is important because of the significant differences between these two types of exploitation in terms of the signaling environment, in which clinical trials are expensive, risky, and time-consuming (DiMasi et al., 2003; Urbig et al., 2013). Overall, $58.6 \%$ of R\&D expenditures for developing a new drug are spent on clinical trials, which may last for an average of 6-7 years (PhRMA, 2010). Yet, there is significant difference between moderate-scale versus large-scale of clinical trials in terms of their different scales and failure rates. Specifically, moderate-scale clinical trials have a small to moderate number of patients (i.e., often less than 100); average expenditure on moderate-scale Phase 1 clinical trials is around \$57 million. However, the figures can jump up to thousands of patients in many different hospitals, and have been said to rise to $\$ 418$ million for late Phase 3 clinical trials (Girotra et al., 2007). While the accumulated probability of failure for preclinical and moderate-scale clinical stages is around 80\% (DiMasi et al., 2003; Moran, 2003), for drugs that have entered the late Phase 3 clinical stage, this figure comes down to just 20-40\% (Himmelmann and Schiereck, 2009; Kellogg and Charnes, 2000).

The question now is how do the above-summarized features of the signaling environment impact the sig- nals investors receive from entrepreneurial firms when they form new co-development alliances?

Given the lengthy time frame of the NPD process for drugs, the way in which investors' interpretation of the signals given depends on the drug development stage at which an alliance is formed can be explained by construal theory (Trope and Liberman, 2003). Construal theory predicts that whether events or actions are viewed in more abstract or more concrete terms depends on how distant they are. To quote Trope and Liberman (2003), "temporal distance changes people's responses to future events by changing the way people mentally represent those events" (p. 403) and "distant future situations are construed on a higher level (i.e., using more abstract and central features) than near future situations" (Liberman and Trope, 1998, p. 5). Here, high-level construal of actions, or how investors interpret events or signals, includes the desirable outcomes, such as the end value that would result from a new alliance. Low-level construal of events or signals focuses on the feasibility of the desired outcome, which refers to "the ease or difficulty of reaching the end state" (Trope and Liberman, 2003, p. 410). For example, for people looking for a job, "desirability concerns the value of receiving a job offer, whereas feasibility concerns the amount of time and effort one has to invest to get the job offer" (Trope and Liberman, 2003, p. 410). Construal theory thus suggests that feasibility matters more for near-future judgments and preferences, such that the "probability dimension becomes more salient as time passes" (Öncüler, 2010, p. 113; Trope and Liberman, 2003). In near-future decisions, people tend to underutilize high-level (desirability) information, whereas in distant-future decisions they tend to underutilize low-level (feasibility) information (Trope and Liberman, 2003).

Thus, construal theory provides a number of insights into drug discovery. When interpreting signals of a firm pursuing an NPD alliance at a downstream development stage, including moderate-scale and large-scale exploitation alliances, investors are likely to emphasize the firm's ability to finalize the project successfully and the feasibility of this happening. Investors' perception will change if such feasibility changes. Hence, the large-scale exploitation stage context is one in which feasibility is higher. In contrast, when judging NPD alliances at the upstream development stage of exploration, investors are less likely to focus on the feasibility of NPD success because the finalization of the development process and the product's market introduction are distant in time. Instead, they will focus more on the desirability of NPD 
success, which concerns the value of a successful new product launch. In fact, distant-future predictions may be made with greater over-confidence than near-future predictions (Trope and Liberman, 2003). This tendency is captured by the behavior of future optimism, where people tend to hold more positive expectancies for distant than near-future outcomes (Mitchell et al., 1997; Trope and Liberman, 2003).

Figure 2 summarizes these arguments. The following section elaborates on the relationships in Figure 2 by describing effects from the historical signals of prior project suspensions and failures on value creation and their respective contingent effects in different signaling environments.

\section{Hypotheses}

\section{Prior NPD Project Suspensions as Signals}

As discussed above, a project may be suspended because of timing issues and constraints affecting financial, technological, knowledge-related, and other resources. The suspended project passes a screening gate; however, once the resource and timing issues have been resolved, it can be reactivated (Cooper, 2003; Cooper and Edgett, 2012; Cooper and Kleinschmidt, 1990). An NPD alliance is one way to resolve these issues as alliance partners can provide the knowledge, technologies, financing, and commercialization expertise needed to reactivate the suspended project at the right time (Ahuja et al., 2008; Barney, 1991; Cohen and Levinthal, 1990; Deeds and Hill, 1996; Rothaermel and Deeds, 2004; Wernerfelt, 1984). Thus, project suspensions may signal to outsiders that the focal firm has robust, marketable ideas on which it cannot capitalize at the time when the project is suspended.

In addition, during the creation of an alliance, the partners tend to conduct a very careful assessment of the entrepreneurial firm, evaluating its characteristics and the signals of the likelihood of the alliance's success. In technology- and science-intensive industries such as biotechnology, prior project suspensions may signal that the firm's NPD portfolio management involves a rigorous decision-making process. In particular, the temporary character of suspensions suggests that the management has decided to give priority to other projects (Cooper and Edgett, 2012), conveying to the partners and investors that the firm does indeed have good, marketable ideas to offer, and that it is competent in NPD management (Kester, Hultink, and Griffin, 2014).

Finally, as discussed earlier, project suspensions are not failures. For an entrepreneurial firm, entering into an alliance may be interpreted by investors as a positive signal that alliances may bring the needed complementary resources for an idea to be made viable (Brown, 1997) and reactivate suspended projects at the right moment for the entrepreneurial firm.

In sum, prior project suspensions signal to investors that the entrepreneurial firm has good ideas that may be activated in a new co-development alliance, and displays positive NPD management abilities. This will lead to higher positive abnormal returns when entrepreneurial firms with prior suspended projects

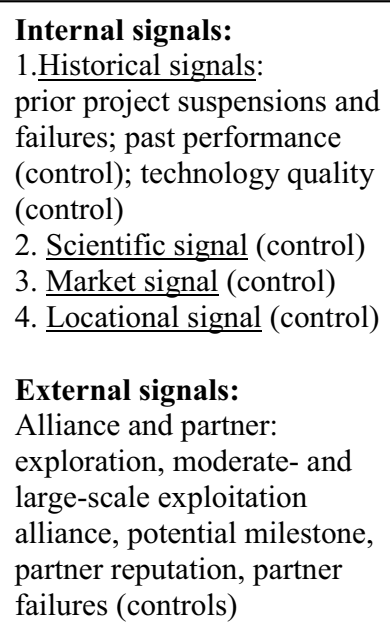

Signaling environment: exploration and moderate- and large- scale exploitation across NPD stages

Figure 2. Conceptual Map

Note: Adapted from Connelly et al. (2011) and Rao et al. (2008). 
announce the formation of a new co-development alliance. Formally:

H1: The prior NPD project suspensions of an entrepreneurial firm have a positive effect on its abnormal returns when it forms a new codevelopment alliance.

\section{Prior NPD Project Failures as Signals}

The technology literature has suggested that firms' technological trajectories are path-dependent (Dosi, 1982). Prior failures may signal declines in future commercial capabilities by reducing desorptive capabilities (Hu, McNamara, and McLoughlin, 2015) and a weakening of future market-oriented innovations ( $\mathrm{Su}$ and McNamara, 2012). Consequently, the firm's past project failures may signal issues in current technology portfolios that decrease attractiveness and increase costs for prospective alliance partners, which in turn is a negative signal to investors about the value a new alliance formation may create.

Prior project failures may also raise doubts about an entrepreneurial firm's ability to learn from them (Shepherd and Cardon, 2009). Learning from failure is critically important to improve future performance, but it is one of the most difficult tasks that an organization performs (Wheelwright and Clark, 1992), in particular because of the negative impact of project failure on individual learning behaviors and psychological well-being (Shepherd, 2003; Shepherd, Covin, and Kuratko, 2009). Hence, an increasing number of prior project failures may signal the firm's difficulties in learning from failure and an increased likelihood of making mistakes in the future.

Finally, prior project failures decrease the bargaining power of the entrepreneurial firm vis-à-vis its alliance partners. In a typical bargaining situation in alliances, the more critical the resources and skills from the partner's perspective, the greater the firm's bargaining power (Makhija and Ganesh, 1997). In high-technology settings, large downstream firms seek NPD partnerships with smaller upstream firms because the latter have intangible resources and unique technological capabilities in niche areas (Chen and Hambrick, 1995; Stuart, 2000). However, if an entrepreneurial firm has a high failure rate where NPD projects are concerned, its bargaining power will decrease and may signal to investors that the entrepreneurial firm's alliance partner may be in a better position to extract value from the new alliance than the firm itself, implying a lower potential value cre- ation by the firm and hence lower abnormal returns when the formation of a new alliance is announced.

In sum, for an entrepreneurial firm, its prior NPD failures signal technological, learning-related, and bargaining-power issues for a new co-development alliance, and these decrease its value-creation potential. These arguments are consistent with prior research in the area of finance which has evidenced negative abnormal returns on clinical failure announcements by biopharmaceutical firms (Girotra et al., 2007). There is also evidence of a negative bias toward NPD failure announcements with stock market declines in response to them being many times greater than the positive response to announcements of success in NPD (Sharma and Lacey, 2004). Taking these arguments together, this research predicts that:

H2: The prior NPD project failures of an entrepreneurial firm have a negative effect on its abnormal returns when it announces the formation of a new co-development alliance.

\section{Signaling Environment: The Contingent Effects of Prior NPD Project Suspensions and Failures}

H1 has predicted that higher levels of prior NPD project suspensions on the part of an entrepreneurial firm are positively associated with abnormal returns realized when the firm announces the formation of a new co-development alliance. In what follows, this research discusses how the strength of this effect depends on the changes in the signaling environment, that is to say the different stages along the explorationexploitation continuum of the NPD process at which alliances are formed.

According to construal theory (Trope and Liberman, 2003), when judging NPD alliance in upstream development stages of exploration, investors are less likely to focus on the feasibility of NPD success because the finalization of the development process and the product's market introduction are distant in time. Instead, investors will focus on the desirability of NPD success. As a result, they will have more optimistic expectations of an alliance which is in the exploration stage than an alliance in a later stage (cf. Mitchell et al., 1997; Trope and Liberman, 2003). This will make them view all signals sent by the entrepreneurial firms, such as signals of marketable ideas and NPD management abilities inferred from prior project 
suspensions, in a more positive light. In this sense, the positive signaling effect of prior NPD project suspensions on abnormal returns when a new NPD alliance is formed, as predicted in $\mathrm{H} 1$, may be stronger when the alliance concerns NPD in the exploration stage than in the exploitation stage.

Compared to exploration alliances, exploitation alliances are less distant in time from the product launch. Hence, for exploitation alliances, the feasibility aspect of successful product launch becomes more prominent than the desirability aspect (Öncüler, 2010). As discussed earlier, the feasibility of NPD success varies significantly between moderate-scale and large-scale exploitations, with a considerably higher failure rate of just below $80 \%$ for moderate-scale exploitation (DiMasi et al., 2003; Moran, 2003) compared to the $20-40 \%$ failure rate of large-scale exploitation (Himmelmann and Schiereck, 2009; Kellogg and Charnes, 2000). As a result, investors' value-creation expectations will be comparatively low for moderatescale exploitation alliances because of the very high failure rate at this stage, and improved for large-scale exploitation alliances because the NPD success rate improves significantly toward the end of the process.

This implies a significant shift in the signaling environment between the moderate-scale and large-scale exploitation stages of the NPD process, with investors having increasingly positive expectations as the feasibility of success (and their desire to focus on it) increases. Hence, the positive signaling effect of prior project suspensions on abnormal returns predicted in H1 will be weaker for co-development alliances engaged in moderate-scale exploitation than for those undertaking large-scale exploitation. Whether there is a significant difference between the signaling effects of prior project suspensions in exploration alliances (when investors focus on the desirability of success and have optimistic expectations) versus large-scale exploitation alliances (when investors focus on the moderate probability of success at $60-80 \%$ ) cannot be determined on a theoretical level.

Combining the above arguments this research predicts that the signaling environment of exploration alliances and large-scale exploitation alliances will be more positive than that of moderate-scale exploitation alliances. Formally:

H3: For an entrepreneurial firm, the positive effect of its prior NPD project suspensions on abnormal returns when a new co-development alliance is formed is stronger for alliances of exploration and

\section{large-scale exploitation than for alliances of moderate-scale exploitation.}

Let us now turn to the contingent signaling effect of prior NPD project failures. H2 has predicted that the prior NPD project failures of an entrepreneurial firm are negatively associated with its abnormal returns when new co-development alliances are formed. Following the signaling and construal theories, on the basis of which this research expects the signaling environment to be less positive for moderate-scale exploitation alliances than for exploration and largescale exploitation alliances, this research further predicts that the negative effect of prior NPD project failures is more pronounced in the case of the former than the latter.

When evaluating an entrepreneurial firm with a high level of prior NPD failures in the exploration stage of a co-development alliance, investors tend to be optimistic (as discussed earlier) and are therefore likely to make insufficient efforts to garner information about the firm's NPD abilities and feasibility to successfully complete the NPD process in the future. For some, negative signals such as prior project failures are deliberately ignored (Öncüler, 2010; Trope and Liberman, 2003). As a result of this optimism, when evaluating firms in exploration alliances, investors will tend to focus on how they can recover from prior NPD failures and on the desirability of possible NPD success (Mitchell et al., 1997; Trope and Liberman, 2003). All these factors contribute to the weaker negative signaling effect of prior project failures for exploration alliances in the upstream of NPD as compared to exploitation alliances.

For exploitation alliances, as discussed earlier, the feasibility of NPD success becomes more salient (Öncüler, 2010), increasing from $20 \%$ for moderatescale exploitation alliances to $60-80 \%$ for large-scale exploitation alliances (DiMasi et al., 2003; Himmelmann and Schiereck, 2009; Kellogg and Charnes, 2000; Moran, 2003). For large-scale exploitation co-development in particular, the NPD process outcomes become more predictable, with the prime focus on exploitative searches for knowledge appropriation, such as developing specific applications or making minor improvements and alterations to current products (Lee, 2011). This may lead to a weaker negative signaling effect on the part of prior NPD project failures in large-scale exploitation alliances than in moderate-scale exploitation alliances.

Therefore, this research predicts that: 
H4: The negative effect of an entrepreneurial firm's prior NPD project failures on abnormal returns when new co-development alliances are formed is stronger in the cases of alliances of moderate-scale exploitation than alliances of exploration and large-scale exploitation.

\section{Methodology}

\section{Data, Sample, and Event Study}

The empirical setting of this study is the biopharmaceutical industry. Data for this study was obtained from industry-specific databases that monitor the alliance and NPD project activities of biopharmaceutical firms, namely Biocentury Archives, Biocentury Financial Center, BioScan, and Pharmaprojects. Additional information about alliances was obtained from the news database Lexis-Nexis, while financial data was obtained from GlobalVantage (accounting data on European firms), Compustat (accounting data on U.S. firms), and DataStream (stock prices and market indices).

The initial sample was the complete set of firms active in the discovery and development of novel drug compounds for human therapeutics between 1996 and 2003 that were listed on eight stock exchanges in the United States and Europe. The choice of sample period was dictated by data availability. The researchers were interested in small and medium-sized entrepreneurial firms and thus excluded all large biopharmaceutical firms with a market capitalization above U.S. \$3 billion in 2002. This filter reflects the unique distribution of firms by capitalization in this industry (Rasmussen, 2010). Recent research has found that a small number of large biopharmaceutical companies dominate the industry. There are an estimated 3500 biopharmaceutical firms globally, of which about $15 \%$ are public companies. The vast majority of these firms are small, with the majority of listed ones having a market capitalization of less than $\$ 250$ million (Rasmussen, 2010). Therefore, the filter of $\$ 3$ billion has the advantage of being able to capture all the small and medium-sized entrepreneurial firms listed in the United States and Europe, and at the same time to screen the very large firms out of the sample (e.g., large biotech firms such as Amgen were therefore excluded). The resulting sample is a representative of all the small and medium-sized entrepreneurial firms listed in the United States and Europe.

In addition, the filter of $\$ 3$ billion leads to a sample comparable to a recent study on small firms by Yang et al. (2014). More detailed comparison with this and other studies is provided in Table 1. While the choice of public companies required for the use of the event study methodology provides methodological advantages (Boyd, Chandy, and Cunha, 2010; Lee and Chen, 2009; Swaminathan and Moorman, 2009), the authors acknowledge the limitations of the data, one of which is that this research has no observations on private firms. The simple comparison of key sample characteristics of different studies provided in Table 1 shows that the average size and age of this study's sample firms is not unlike those used in other studies. Some examples of the sample entrepreneurial firms and their partners are provided in Table 2 .

Table 1. A Comparison of the Sample with Those of Prior Studies

\begin{tabular}{|c|c|c|c|}
\hline Name of the study & Sample & Firm size & Firm age \\
\hline Rothaermel and Deeds (2006) & $\begin{array}{l}325 \text { fully dedicated biotechnology firms that participated in } 2226 \text { R\&D } \\
\text { alliances between } 1973 \text { and 1997, including public and private firms }\end{array}$ & 161 & 9.6 \\
\hline De Carolis et al. (2009) & $\begin{array}{l}57 \text { public biotechnology companies in the United States and Canada (1992- } \\
\text { 2003) }\end{array}$ & 798 & 13.06 \\
\hline Rao et al. (2008) & $\begin{array}{l}\text { All public biotechnology firms with } 93 \text { product introductions from } 1982 \text { to } \\
2002 \text { in the United States }\end{array}$ & 550 & 15.39 \\
\hline Yang et al. (2014) & $\begin{array}{l}\text { All small biotechnology firms founded between } 1984 \text { and } 1992 \text { that generated } \\
\text { revenues lower than } \$ 100 \text { million from } 1984 \text { to } 2006 \text { in the United States }\end{array}$ & 191 & 12.03 \\
\hline Deeds and Hill (1996) & $\begin{array}{l}\text { All } 132 \text { firms engaged in biotechnology in the United States as of } 1991 \text { that } \\
\text { were developing in vivo therapeutics or diagnostics (including public and } \\
\text { private firms) }\end{array}$ & N/A & 7.69 \\
\hline Our study sample & $\begin{array}{l}126 \text { public firms listed on eight stock exchanges in the United States and } \\
\text { Europe between } 1996 \text { and } 2003\end{array}$ & 210 & 10 \\
\hline
\end{tabular}

Note: A simple analysis was conducted by comparing the key variables of this study's sample with previous studies. Specifically, the size (measured by number of employees) and age of firms were compared, since these are the only data available across different studies. Although the comparison is rather indicative in nature, it shows that this study's sample is similar in size and age to the samples included in the previous studies. 
Table 2. A Selection of Entrepreneurial Firms and Their Partners in the Sample

\begin{tabular}{lll}
\hline Firm & Partners & Location of the firm \\
\hline Acambis Plc & Novartis & United Kingdom \\
Arqule Inc & Bayer & United States \\
Genset SA & Abbott Laboratories & France \\
Karo Bio AB & Abbott Laboratories & Sweden \\
Oxford Glycosciences & Merck & United Kingdom \\
Phytopharm Plc & Pfizer & United Kingdom \\
\hline
\end{tabular}

Note: The table provides an illustration of the entrepreneurial firms together with their partners. Additional data for all of the sample firms indicates that the mean value of the total number of project failures during the observation period for entrepreneurial firms is around 15, while for the partner firms, this figure stands at 126 .

The filter generated a sample of 126 entrepreneurial firms, which made 2453 alliance announcements. The research purpose was to understand the signaling effects of new bi-party co-development alliances and so this research eliminated any multi-party alliances and follow-up agreements or contract extensions. Following good practice, all announcements confounded with other value-relevant news in a window of \pm 3 days around the focal announcement date were identified and eliminated (McWilliams and Siegel, 1997). Examples of confounding events included the announcement of financial results, among others. This reduced the number of firms to 104 and the number of alliance announcements to 327. After accounting for missing data, the final sample used for hypotheses testing included 248 observations. Statistical analyses were conducted to check if there was any issue with the missing data. First, a $t$-test was used comparing the mean of all the key variables between the missing and nonmissing groups. The results were not significant. Second, a logistic regression was used predicting missing data points $(0=$ not missing, $1=$ missing $)$ from all the key variables, and none of them were significant. These results suggest that missing data is not an issue.

\section{Dependent Variable}

The event study method identifies abnormal movement in a firm's stock price (i.e., abnormal returns) on the day the firm announces the formation of an alliance. Abnormal returns are used as proxy for value creation as a result of the new alliance and are therefore appropriate for testing the predicted signaling effects and their contingencies. This research took the earliest alliance announcement date reported in Biocentury Archives, in Lexis-Nexis, or on the company's website and used abnormal returns noted on this day (provided it was a trading day) as the dependent variable. Following Boyd et al. (2010), the market model of the event study method was used to define the event of interest as $\mathrm{k}$ and the event announcement day as $\mathrm{t}$, and the rate of return on the stock price of firm $i$ on day $t$ was estimated according to the following formula:

$$
\mathrm{R}_{\mathrm{it}}=\mathrm{a}_{\mathrm{i}}+\mathrm{b}_{\mathrm{i}} \mathrm{R}_{\mathrm{mt}}+\mathrm{e}_{\mathrm{it}},
$$

in which $R_{i t}$ represents the rate of return on the stock price of firm $i$ on day $t ; R_{m t}$ represents the corresponding daily returns using the index of the local stock market on day t, including the Nasdaq Composite Index in the United States, the FTAllshare in the UK, and, for European-listed firms the composite or best available market index for that stock exchange; $a_{i}$ indicates the intercept term; $b_{i}$ represents the systematic risk of stock $\mathrm{i}$; and $\mathrm{e}_{\mathrm{it}}$ stands for the residual of the estimation.

Next, abnormal returns $\left(\mathrm{AR}_{\mathrm{it}}\right)$ for each firm were estimated using the following equation:

$$
\mathrm{e}_{\mathrm{it}}=\mathrm{AR}_{\mathrm{it}}=\mathrm{R}_{\mathrm{it}}-\left(\mathrm{a}_{\mathrm{i}}+\mathrm{b}_{\mathrm{i}} \mathrm{R}_{\mathrm{mt}}\right) \text {, }
$$

from which the researchers obtained the ordinary least squares parameter estimates by running regressions of $\mathrm{R}_{\mathrm{it}}$ on $\mathrm{R}_{\mathrm{mt}}$ over a period of 250 days before the event $\mathrm{k}$ (Boyd et al., 2010).

Thus, in generating the abnormal returns dependent variable, this research employed the event study method taking into account the multi-country setting of this study (Park, 2004), eliminating observations with confounding events (McWilliams and Siegel, 1997), and avoiding the use of a single expectedreturns model (Chatterjee, Lubatkin, and Schulze, 1999). This methodology was adopted from the finance literature and corporate governance studies (McConnell and Nantell, 1985). It has been employed extensively to study alliances (Gulati et al., 2009), and in innovation and marketing research (Boyd et al., 2010; Lee and Chen, 2009; Swaminathan and Moorman, 2009).

Table 3 presents the means, standard deviations and T-statistics for abnormal returns on each of the trading days from $\mathrm{t}=-5$ to $\mathrm{t}=5(N=248)$. Except for the day 0 , no other day's abnormal returns differed from 0 significantly. The results indicate the accuracy of the date of the first public announcement of alliance this research identified. Thanks to this accuracy, gains from alliance formation for the entrepreneurial firms measured in this study are not only significant but also 
Table 3. Abnormal Returns

\begin{tabular}{lcll}
\hline Abnormal returns day & Mean & Std. dev. & T-statistic \\
\hline$t=-5$ & -0.0019 & 0.052777 & -0.5688 \\
$t=-4$ & -0.00159 & 0.044607 & -0.5631 \\
$t=-3$ & -0.00156 & 0.052255 & -0.473 \\
$t=-2$ & -0.00176 & 0.052682 & -0.5284 \\
$t=-1$ & -0.00155 & 0.048377 & -0.5076 \\
$t=0$ & 0.048913 & 0.117136 & $6.6024 * * *$ \\
$t=1$ & -0.00096 & 0.059488 & -0.2558 \\
$t=2$ & -0.0032 & 0.043371 & -1.1652 \\
$t=3$ & 0.003779 & 0.044145 & 1.3534 \\
$t=4$ & -0.00078 & 0.055028 & -0.223 \\
$t=5$ & -0.0067 & 0.04853 & -2.1818 \\
\hline
\end{tabular}

$N=248 ; * * * p<0.001$.

higher than some of the previous findings. Some of the reasons for these higher returns include the focus on smaller firms than many studies (Chang and Chen, 2002; Das, Sen, and Sengupta, 1998; Lee and Wyatt, 1990; Reuer and Koza, 2000) and the choice of R\&D intensive firms.

\section{Independent Variables}

Prior project suspensions. This variable is calculated as the accumulated number of all prior NPD project suspensions on the part of the entrepreneurial firm from 1990 until the day prior to the focal alliance announcement (obtained from the Pharmaprojects database). As an alternative, this variable was also measured as the ratio of the total number of suspended projects to the total number of all the drug development initiatives in the focal firm in the period from 1990 to the year prior to the given event year. The results are consistent.

Prior project failures. This variable is calculated as the total number of a focal firm's ceased drug development initiatives from 1990 until the day prior to the focal alliance announcement. This variable was also measured as the ratio of the total number of ceased drug development initiatives to the total number of all the drug development initiatives in a focal firm in the period from 1990 to the year prior to the given event year (data from Pharmaprojects). The results are consistent.

Exploration, moderate-scale, and large-scale exploitation alliances dummy variables. The three phases of the drug development process were captured using dummy variables. Following previous research (Rothaermel and Deeds, 2004; Urbig et al., 2013), exploration alliances were defined as ones that focus on upstream NPD activities (i.e., basic research, drug discovery, and development), moderate-scale exploitation alliances as ones that focus on moderate-scale downstream NPD activities (Phase 1 and 2 clinical trials), and large-scale exploitation alliances as those focusing on large-scale downstream NPD activities (including Phase 3 clinical trials, the regulatory process, and marketing and sales; see Figure 1).

\section{Control Variables}

Following the conceptual framework (Figure 2), in terms of internal signals, this research controlled for two historical signals studied in prior literature: past performance and technology quality. Scientific, market, and locational signals were also included as control variables. In terms of external signals, controls for potential milestone, partner reputation, and partner failures were included.

Past performance. A firm's previous performance may influence how investors evaluate the shareholder value of its current event announcement (Robertson, Eliashberg, and Rymon, 1995). In keeping with prior literature (Lee and Chen, 2009), past performance was measured using lagged Tobin's q.

Technology quality. One important way for pharmaceutical firms to appraise the prospects of biotechnology firms is by evaluating their patent portfolios (Rothaermel, 2002). Prior literature used the number of citations that a patent receives as a proxy for the value of patents (Fleming and Sorenson, 2001). This research therefore used the natural logarithm of cumulative patent citations to measure the quality of the firm's technology prior to the alliance announcement.

Scientific signal. This variable was measured as the number of academics on the board of the entrepreneurial firm (Rao et al., 2008). The data sources for this were LexisNexis and SEC filings.

Market signal. This variable was measured as the estimated market size of the therapeutic category and signals the market potential of the drug which is the subject of the new alliance. This data came from Pharmaproject.

Locational signal. This is a dummy variable indicating the geographical location of the firm. It is equal 
to 1 for a European firm and 0 for a U.S.-based firm. This data came from company websites.

Own potential milestone. In co-development alliances, one alliance partner may provide financial payments to another contingent on passing a given development milestone. At the time of the formation of the alliance, the financial value of these milestone payments is often disclosed to the market. This amount of money represents the total that would be paid if all developmental milestones were met, however these are stretching targets and few projects actually achieve all milestones. These milestone payments are informative for investors in that they demonstrate part of the value that the partner sees in the project if it were fully successful and the amount of funds that are available to support the costs of NPD. This data came from Biocentury Archives, Biocentury Financial Center, BioScan, and Pharmaprojects and is used in logged form in the regression analysis.

Partner reputation. Following prior literature (Hitt, Dacin, Levitas, Arregle, and Borza, 2000; Stuart, 2000), a partner dummy was included to model a partner's reputation and experiences in NPD. Specifically, the partner dummy is equal to 1 if an alliance partner was listed among the top 20 companies in the biopharmaceutical industry in terms of the number of $R \& D$ clinical trials originated and in-licensed by a firm in the year of the focal alliance announcement; otherwise, the variable equals 0 . This variable was obtained from Pharmaprojects and updated yearly.

Partner project failures. Partner firms' failures were measured as the ratio of the total number of ceased drug development initiatives to the total number of all the drug development initiatives in a partner firm in the period from 1990 to the year prior to the given event year (data from Pharmaprojects). As an alternative, this variable was also measured as a count variable, and the results remained unchanged. Since a partner with a larger number of NPD projects tends to experience higher number of failures (other things being equal), the count variable may control for the partner's R\&D scale to some extent.

Besides controlling for signaling effects not focal to this study, other factors that may have an impact on abnormal returns and have been used in prior literatures were also included. These are as follows.
Firm age. Number of calendar years after the establishment of the firm.

Firm size. Lagged employee count divided by 1000.

$R \& D$ scale. Lagged amount of $\mathrm{R} \& \mathrm{D}$ expenditure divided by 1 million.

Financial slack. Equity-to-debt ratio, i.e., (total assets - total liabilities)/total liabilities, was used to measure this variable. This ratio indicates a firm's unused borrowing capacity (Cheng and Kesner, 1997), which captures the concept of unabsorbed slack. The extant literature suggests that budgetary slack causes the relaxation of controls, thereby allowing more autonomy in project teams (Nohria and Gulati, 1996), and possibly leading to better NPD outcomes (Bourgeois, 1981).

Alliance experience. Prior literature has suggested that alliance experience is an important determinant of abnormal returns to strategic alliances in general (Anand and Khanna, 2000; Sampson, 2005). Alliance experience was measured as a 1-year lagged and logged count of all alliances the focal firm had prior to the focal alliance, starting from 1990 or the year of the firm's establishment, whichever was later. Data were obtained from company alliance portfolios listed on an annual basis in BioScan and Pharmaprojects, supplemented with alliances identified through LexisNexis.

\section{Analysis}

To test the hypotheses, all independent and control variables were regressed on the abnormal returns using White's covariance matrix estimator to control for potential heteroskedasticity, with an additional adjustment for within-group dependence of observations in the sample per firm (the "cluster" procedure; StataCorp, 2007). This accounted for firm-specific effects. All continuous independent variables were winsorized at the $2.5 \%$ level and mean-centered. Winsorization eliminates the potential effects of outliers by replacing extreme values in each variable with the next respective value, counting inwards from the extremes (OrtizMolina, 2006). Mean-centering prevents the occurrence of collinearity problems and facilitates the interpretation of the estimation results where multiplicative terms are used (Aiken and West, 1991). 
A variance inflation factor (VIF) test found that the average VIF value was 2.4 with all of the VIF values well below the critical value of 10 , indicating that collinearity is unlikely to be an issue in the models. To avoid potential multicollinearity and following prior research (e.g., Stuart et al., 1999), the interaction effects were introduced in separate models. The full model was also included.

\section{Results}

Table 4 provides the descriptive statistics and correlation matrices for the variables used in the study. From Table 4, it is evident that there is considerable variance in abnormal returns and focal independent variables in this study. Furthermore, the correlation coefficient between prior project suspensions and project failures (0.20) indicates consistency with the idea that these can function as different signals.

Table 5 presents the results of the regression analysis with robust errors. Models $0-5$ reveal that control variables produced mostly insignificant effects on abnormal returns. This is similar to some prior research that found no support for the effects of firm size (Anand and Khanna, 2000) on abnormal returns following alliance announcements. There are some notable observations for the control variables. First, the partner reputation dummy variable is always significantly positive, suggesting that allying with top-20 companies in the biopharmaceutical industry increases abnormal returns. This effect is not surprising, considering the insights from many prior alliance studies on entrepreneurial firms (Stuart, 2000; Stuart et al., 1999). Second, the signs of past performance are always positive, which is in line with the literature on path dependence and the conceptualization of historical signals in this study. Third, the alliance experience variable is always negative. This is consistent with the patterns reflected in the findings of Gulati et al. (2009), suggesting that general alliance experience does not contribute positively to abnormal returns. This result also alludes to the difficulty of learning from alliance experience.

In Model 1, the main effect of prior project suspensions was included. The result is positive and significant $(\beta=0.023, p<0.05)$. The result supports $\mathrm{H} 1$, which predicted that prior suspended projects are positive signals about the entrepreneurial firm's potential to create value from a new alliance.
$\mathrm{H} 2$ predicted that prior project failures would have a negative signaling effect on abnormal returns. In line with this hypothesis, in Model 2, the prior project failures variable is significant and negative $(\beta=-0.195$, $p<0.01$ ). Models $3-5$ render further support to the hypothesis.

Models 3 and 4 introduce interaction effects to test $\mathrm{H} 3$ and H4. Moderate-scale exploitation alliances are always used as the reference group. Specifically, in Model 3, the first interaction effects of interest were entered: how the NPD stage at which the alliances are formed (i.e., exploration and moderate and large-scale exploitation) moderates the positive effect of suspended projects. According to $\mathrm{H} 3$, the positive effect of prior project suspensions on abnormal returns is stronger for alliances of explorations and large-scale exploitations than for alliances of moderate-scale exploitations. The positive and significant result of the interaction term between "prior project suspensions" and "exploration alliance dummy" $(\beta=0.029, p<$ 0.01 ), and the positive but insignificant result of interaction term between "prior project suspensions" and "large-scale exploitation alliance dummy" $(\beta=0.044$, $p=0.31)$ partially support this hypothesis. While the positive sign with the large-scale exploitation alliance is in line with the hypothesis, its insignificance is worthy of further explanation. One possible reason for it could be that investors pay less attention to the signal from the prior project suspensions of the entrepreneurial firm, but more attention to the failure signal from the partner firms within a large-scale exploitation alliance. In Model 5, the significant interaction term between partner failures and a large-scale exploitation alliance $(\beta=0.589, p<0.05)$ indicates that this is a possibility, suggesting a noteworthy effect from the failure signal of partner firms when forming a largescale exploitation alliance.

Model 4 tested how the negative effect of prior failures is moderated by the NPD stage at which alliances are formed. According to $\mathrm{H} 4$, this relationship is more pronounced for moderate-scale exploitation alliances than for exploration and large-scale exploitation alliances. The positive sign of the interaction term between "prior project failures" and "exploration alliance dummy" from Model $4(\beta=0.253, p<0.100)$ and the insignificant results of interaction term between "prior project failure" and "large-scale exploitation alliance dummy" ( $\beta=-0.132, p=0.574)$ partially support this hypothesis. The negative sign of the latter interaction term is intriguing. One possible explanation could be discerned in the observations that 


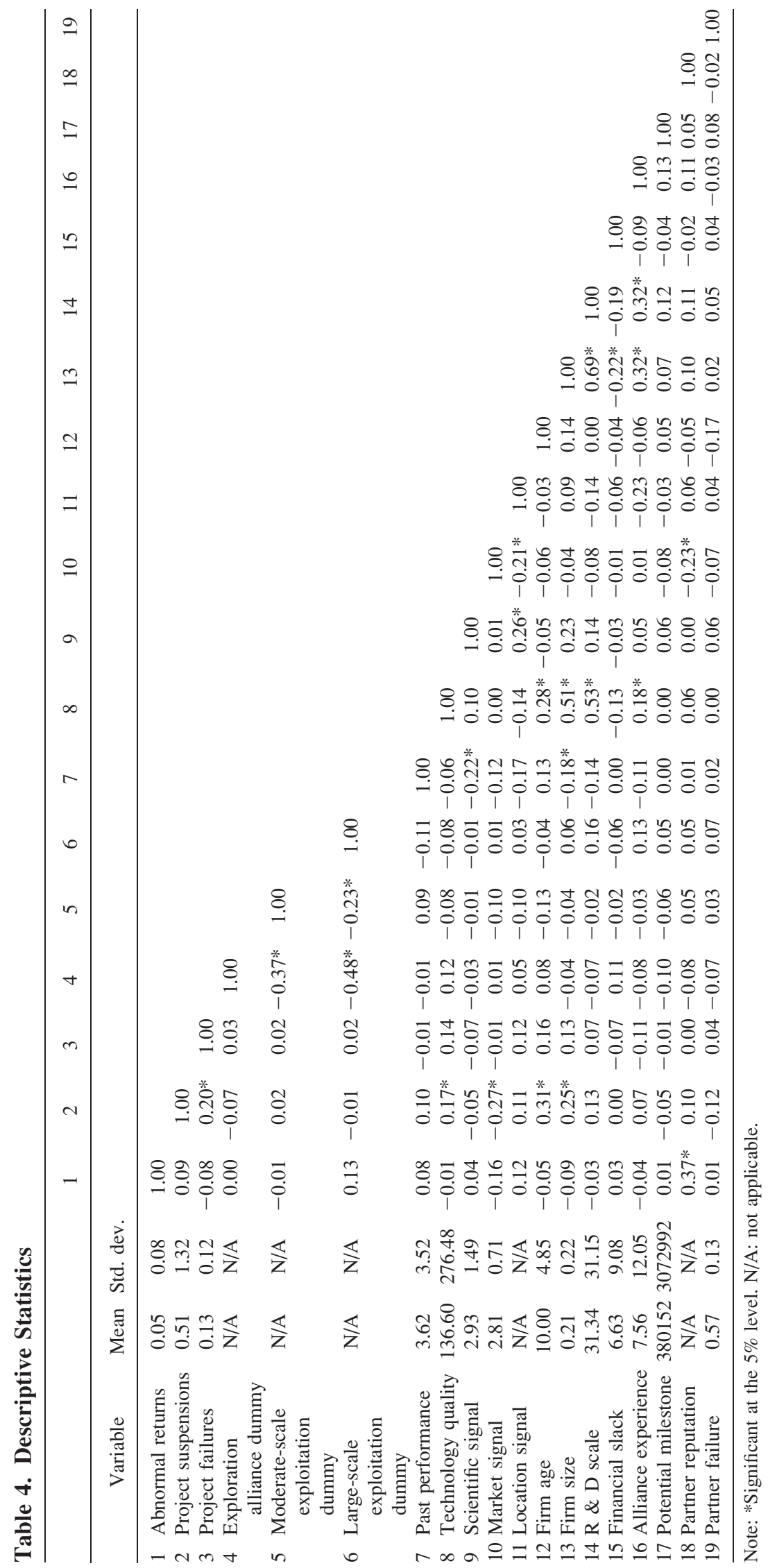


Table 5. Results of Multiple Regression Analyses of Abnormal Returns

\begin{tabular}{|c|c|c|c|c|c|c|c|}
\hline & Model 0 & Model 1 & Model 2 & Model 3 & Model 4 & Model 5 & VIF \\
\hline Firm age & $\begin{array}{c}-0.004 \\
(0.002)\end{array}$ & $\begin{array}{r}-0.005 \\
(0.003)\end{array}$ & $\begin{array}{c}-0.003 \\
(0.002)\end{array}$ & $\begin{array}{r}-0.003 \\
(0.002)\end{array}$ & $\begin{array}{c}-0.002 \\
(0.003)\end{array}$ & $\begin{array}{c}-0.001 \\
(0.003)\end{array}$ & 2.66 \\
\hline Firm size & $\begin{array}{c}-0.200 \\
(0.136)\end{array}$ & $\begin{array}{c}-0.136 \\
(0.121)\end{array}$ & $\begin{array}{c}0.047 \\
(0.128)\end{array}$ & $\begin{array}{c}0.081 \\
(0.129)\end{array}$ & $\begin{array}{c}0.122 \\
(0.152)\end{array}$ & $\begin{array}{c}0.147 \\
(0.123)\end{array}$ & 4.36 \\
\hline $\mathrm{R} \& \mathrm{D}$ scale & $\begin{array}{c}-0.004 \\
(0.008)\end{array}$ & $\begin{array}{c}-0.005 \\
(0.009)\end{array}$ & $\begin{array}{r}-0.010 \\
(0.010)\end{array}$ & $\begin{array}{c}-0.012 \\
(0.010)\end{array}$ & $\begin{array}{c}0.000 \\
(0.000)\end{array}$ & $\begin{array}{c}-0.002 \\
(0.011)\end{array}$ & 2.67 \\
\hline Financial slack & $\begin{array}{c}0.000 \\
(0.001)\end{array}$ & $\begin{array}{c}0.001 \\
(0.001)\end{array}$ & $\begin{array}{c}0.001 \\
(0.001)\end{array}$ & $\begin{array}{c}0.001 \\
(0.001)\end{array}$ & $\begin{array}{c}0.001 \\
(0.001)\end{array}$ & $\begin{array}{c}0.005 \\
(0.012)\end{array}$ & 2.45 \\
\hline Alliance experience & $\begin{array}{r}-0.006 \\
(0.017)\end{array}$ & $\begin{array}{r}-0.013 \\
(0.017)\end{array}$ & $\begin{array}{r}-0.022 \\
(0.015)\end{array}$ & $\begin{array}{c}-0.023 \\
(0.015)\end{array}$ & $\begin{array}{c}-0.025 \\
(0.013)\end{array}$ & $\begin{array}{c}-0.022 \\
(0.012)\end{array}$ & 2.35 \\
\hline Potential milestone & $\begin{array}{c}-0.002 \\
(0.003)\end{array}$ & $\begin{array}{c}0.000 \\
(0.003)\end{array}$ & $\begin{array}{c}-0.001 \\
(0.003)\end{array}$ & $\begin{array}{c}-0.002 \\
(0.003)\end{array}$ & $\begin{array}{c}-0.001 \\
(0.003)\end{array}$ & $\begin{array}{c}-0.002 \\
(0.003)\end{array}$ & 1.67 \\
\hline Exploration alliance dummy & $\begin{array}{c}-0.015 \\
(0.022)\end{array}$ & $\begin{array}{r}-0.016 \\
(0.019)\end{array}$ & $\begin{array}{c}-0.023 \\
(0.019)\end{array}$ & $\begin{array}{c}-0.025 \\
(0.017)\end{array}$ & $\begin{array}{c}-0.029 \\
(0.022)\end{array}$ & $\begin{array}{c}-0.033 \\
(0.021)\end{array}$ & 1.77 \\
\hline Large-scale exploitation dummy & $\begin{array}{c}0.010 \\
(0.029)\end{array}$ & $\begin{array}{c}0.014 \\
(0.029)\end{array}$ & $\begin{array}{c}0.015 \\
(0.032)\end{array}$ & $\begin{array}{c}0.024 \\
(0.035)\end{array}$ & $\begin{array}{c}0.005 \\
(0.026)\end{array}$ & $\begin{array}{c}0.032 \\
(0.027)\end{array}$ & 2.10 \\
\hline Partner reputation & $\begin{array}{l}0.110 * * \\
(0.031)\end{array}$ & $\begin{array}{l}0.111^{* *} \\
(0.031)\end{array}$ & $\begin{array}{l}0.109^{* *} \\
(0.032)\end{array}$ & $\begin{array}{l}0.101^{* *} \\
(0.033)\end{array}$ & $\begin{array}{l}0.104 * * * \\
(0.026)\end{array}$ & $\begin{array}{l}0.096^{* * * *} \\
(0.025)\end{array}$ & 1.67 \\
\hline Partner failure & $\begin{array}{c}0.058 \\
(0.061)\end{array}$ & $\begin{array}{c}0.075 \\
(0.063)\end{array}$ & $\begin{array}{c}0.115 \\
(0.070)\end{array}$ & $\begin{array}{c}0.108 \\
(0.073)\end{array}$ & $\begin{array}{c}0.109 \\
(0.079)\end{array}$ & $\begin{array}{c}0.024 \\
(0.103)\end{array}$ & 2.69 \\
\hline Scientific signal & $\begin{array}{c}0.000 \\
(0.006)\end{array}$ & $\begin{array}{c}0.003 \\
(0.006)\end{array}$ & $\begin{array}{c}-0.004 \\
(0.006)\end{array}$ & $\begin{array}{c}-0.007 \\
(0.006)\end{array}$ & $\begin{array}{c}-0.006 \\
(0.008)\end{array}$ & $\begin{array}{c}-0.012 \\
(0.007)\end{array}$ & 1.95 \\
\hline Market signal & $\begin{array}{c}0.005 \\
(0.015)\end{array}$ & $\begin{array}{c}0.008 \\
(0.014)\end{array}$ & $\begin{array}{c}0.002 \\
(0.015)\end{array}$ & $\begin{array}{c}-0.004 \\
(0.017)\end{array}$ & $\begin{array}{c}-0.005 \\
(0.016)\end{array}$ & $\begin{array}{c}-0.018 \\
(0.015)\end{array}$ & 1.47 \\
\hline Location signal & $\begin{array}{c}0.007 \\
(0.028)\end{array}$ & $\begin{array}{c}-0.003 \\
(0.027)\end{array}$ & $\begin{array}{c}0.013 \\
(0.027)\end{array}$ & $\begin{array}{c}0.011 \\
(0.026)\end{array}$ & $\begin{array}{c}0.025 \\
(0.028)\end{array}$ & $\begin{array}{c}0.031 \\
(0.027)\end{array}$ & 2.11 \\
\hline Historical signal: past performance & $\begin{array}{c}0.004 \\
(0.003)\end{array}$ & $\begin{array}{c}0.005 \\
(0.003)\end{array}$ & $\begin{array}{c}0.004 \\
(0.003)\end{array}$ & $\begin{array}{c}0.004 \\
(0.003)\end{array}$ & $\begin{array}{c}0.005 \\
(0.003)\end{array}$ & $\begin{array}{c}0.006 \\
(0.003)\end{array}$ & 1.66 \\
\hline Historical signal: technology quality & $\begin{array}{c}0.011 \\
(0.006)\end{array}$ & $\begin{array}{c}0.009 \\
(0.006)\end{array}$ & $\begin{array}{c}0.004 \\
(0.007)\end{array}$ & $\begin{array}{c}0.004 \\
(0.007)\end{array}$ & $\begin{array}{c}-0.001 \\
(0.008)\end{array}$ & $\begin{array}{c}-0.005 \\
(0.008)\end{array}$ & 4.16 \\
\hline Prior project suspensions & & $\begin{array}{c}0.023^{*} \\
(0.010)\end{array}$ & $\begin{array}{c}0.025^{*} \\
(0.011)\end{array}$ & $\begin{array}{c}0.007 \\
(0.010)\end{array}$ & $\begin{array}{c}0.027^{*} \\
(0.010)\end{array}$ & $\begin{array}{c}0.005 \\
(0.013)\end{array}$ & 3.41 \\
\hline Prior project failures & & & $\begin{array}{c}-0.195^{* *} \\
(0.068)\end{array}$ & $\begin{array}{c}-0.209^{* *} \\
(0.070)\end{array}$ & $\begin{array}{r}-0.307 * \\
(0.113)\end{array}$ & $\begin{array}{c}-0.350^{* *} \\
(0.110)\end{array}$ & 2.59 \\
\hline Prior project suspensions $\times$ Exploration alliance dummy & & & & $\begin{array}{l}0.029 * * \\
(0.010)\end{array}$ & & $\begin{array}{c}0.032 \\
(0.017)\end{array}$ & 2.70 \\
\hline Prior project suspensions $\times$ Large-scale exploitation alliance & dummy & & & $\begin{array}{c}0.044 \\
(0.043)\end{array}$ & & $\begin{array}{c}0.046 \\
(0.032)\end{array}$ & 1.55 \\
\hline Prior project failures $\times$ Exploration alliance dummy & & & & & $\begin{array}{c}0.253 \\
(0.150)\end{array}$ & $\begin{array}{c}0.289 \\
(0.146)\end{array}$ & 2.59 \\
\hline Prior project failures $\times$ Large-scale exploitation alliance dum & my & & & & $\begin{array}{c}-0.132 \\
(0.207)\end{array}$ & $\begin{array}{c}-0.128 \\
(0.196)\end{array}$ & 1.52 \\
\hline Partner failures $\times$ Exploration alliance dummy & & & & & & $\begin{array}{c}0.029 \\
(0.149)\end{array}$ & 2.28 \\
\hline Partner failures $\times$ Large-scale exploitation alliance dummy & & & & & & $\begin{array}{c}0.589 * \\
(0.235)\end{array}$ & 1.67 \\
\hline Constant & $\begin{array}{c}0.016 \\
(0.066)\end{array}$ & $\begin{array}{r}-0.018 \\
(0.064)\end{array}$ & $\begin{array}{c}0.009 \\
(0.077)\end{array}$ & $\begin{array}{c}0.053 \\
(0.084)\end{array}$ & $\begin{array}{c}0.044 \\
(0.077)\end{array}$ & $\begin{array}{c}0.146 \\
(0.098)\end{array}$ & \\
\hline Adjusted $\mathrm{R}^{2}$ & 0.26 & 0.33 & 0.40 & 0.42 & 0.43 & 0.51 & \\
\hline
\end{tabular}

Note: $N=248$. The estimated coefficients and the robust standard errors (in parentheses below the estimates) have been adjusted for clustering by company. In Model 3-5 where the interaction effects are included, a moderate-scale exploitation alliance dummy is used as the reference group. Significance levels are two-tailed. $* p<0.05, * * p<0.01, * * * p<0.001$.

prior failures are associated with rising operational costs (Baum and Dahlin, 2007), which is a big concern at the exploitation stage, where investments in largescale clinical trials are much higher than at moderatescale stages. The perceptions of such increased cost might have led to a less favorable perception of the "feasibility" of prior project failures, suggesting higher investment to reach final launch. The other possible explanation could come from the finance literature, which has demonstrated a bias against failure in the 
Table 6. The Effect of Prior Project Suspensions and Failures on Actual Projects that Were Ultimately Successful NPD Launches

\begin{tabular}{lc}
\hline Variables & \\
\hline Firm age & 0.00 \\
& $(0.01)$ \\
Past performance & 0.01 \\
& $(0.01)$ \\
Financial slack & 0.01 \\
& $(0.00)$ \\
Firm size & $2.51^{* * *}$ \\
& $(0.60)$ \\
Alliance experience & -0.10 \\
& $(0.06)$ \\
R \& D scale & 0.00 \\
& $(0.00)$ \\
Technology quality & $0.10^{*}$ \\
Location dummy & $(0.05)$ \\
& $1.49 * * *$ \\
Partner reputation & $(0.36)$ \\
Partner failure & 0.06 \\
& $(0.11)$ \\
Lagged suspended projects & 0.26 \\
Lagged failed projects & $(0.35)$ \\
Constant & $0.12^{*}$ \\
& $(0.06)$ \\
& -0.04 \\
No: & $(0.02)$ \\
& -0.18 \\
& $(0.24)$ \\
\hline
\end{tabular}

Note: Dependent variable $=\mathrm{Ln}$ (number of successful product launches); $N=54$, adjusted $R^{2}=0.81$. The positive and significant sign of firm size suggests that larger firms achieve more successful launches. This is also true for technology quality and location dummy for firms based in Europe, and for project suspensions. Prior failed projects are negatively linked to successful launches. The results remain robust after controlling for year fixed effect and firm fixed effects.

As robustness checks, a Poisson regression was run using the number of successful product launches (a count variable) as the dependent variable, with other independent variables included above. The results remain largely unchanged. Bootstrapping regressions were run, and the substantive results remain largely unchanged.

$* p<0.05, * * p<0.01, * * * p<0.001$

financial markets. At the large-scale exploitation stage, investors can be very sensitive to past failures and may therefore react negatively.

Model 5 is the full model. The results are consistent with the major findings of the partial Models 1-4, and support the hypotheses.

\section{Robustness Checks and Additional Analyses}

To test the robustness of the results, a number of additional analyses were performed to address the following questions.

\section{How Do Prior Project Suspensions and Failures Influence Actual Successful NPD Launches?}

The analyses show that prior project suspensions increase the value-creation potential of new codevelopment alliances, while prior failures decrease it. However, it is not clear how prior suspensions and failures affect actual product development rather than the instant effect of the stock market response. The answers to such questions could generate new insights. Therefore, two additional analyses were conducted as follows. First was a regression model using successful product launches as the dependent variable, and oneyear lagged prior project suspensions and prior project failures as independent variables, together with the other control variables included in the models in Table 5. The results in Table 6 suggest that prior project suspensions have a significantly positive effect on actual product launches, while prior project failures have a negative one. Next, a logistic model with prior project suspensions and failures was used to predict success in product launches. Again the results (not shown here to save space) confirm that prior project suspensions can effectively predict successful product launch.

\section{How Are the Empirical Measures of Suspensions and Failures Consistent with the Conceptualization?}

The two variables of project suspensions and project failures are conceptually distinct. For example, project suspensions should be temporary in nature, and longterm suspensions could be seen as failures. Empirically, it is necessary to know more about the differences between the failure and suspension measures in the context of NPD in the biopharmaceutical industry. To address these issues, further analyses were conducted.

This study used data on project suspensions and failures from the Pharmaprojects database. Pharmaprojects scans relevant publications and contacts companies directly to keep track of the drug development activity in the industry. According to its manual, project suspension is defined as project "development suspended with the possibility of restarting," while project failure is defined as "development terminated." In addition to the two types of status of NPD projects, Pharmaprojects also records a third type, namely "no development reported," meaning "no evidence of continuing development reported." A product profile is 


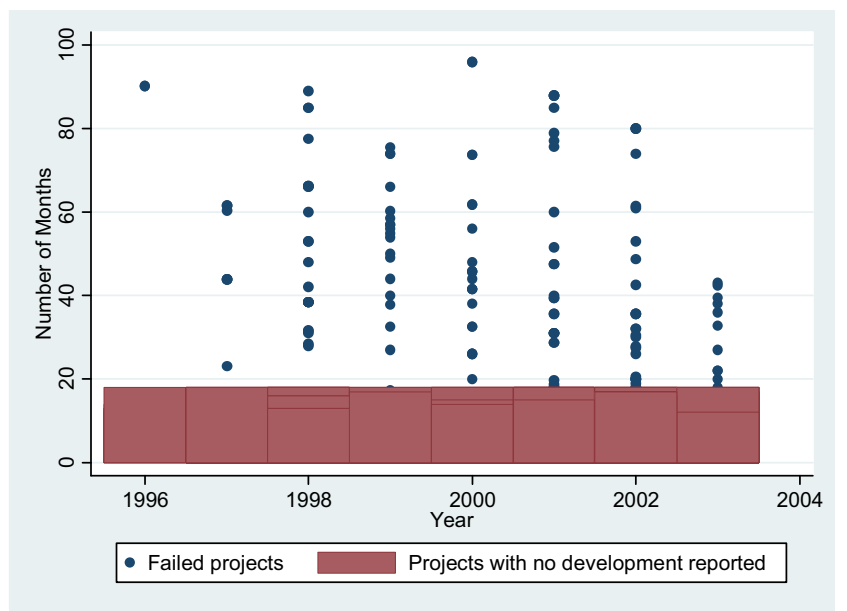

Figure 3. A Comparison of the Time during which Projects Are Designated as Failed Projects, Projects with No Development Reported, and Suspended Projects

Note: As indicated by the dots in the figure, the number of months from the start to the final termination of a failed project is significantly larger than the number of months in which a project can keep its status as "no development reported" (as indicated by the region in the shaded box). Since the duration of project suspensions is less than or at the most equal to the maximum number of months for which a project can be labeled as "no development reported," their duration falls within the shaded box (i.e., between 0 and 18 months).

designated as "no development reported" when no new information or evidence of continuing development has been found for a period of around 12-18 months. This label remains until active development resumes or the company confirms that the drug has been discontinued or terminated.

By this definition, no project can be designated in the database as "suspended" longer than 12-18 months. If a suspension lasts for over 18 months, it will be labeled as "no development reported," and in this case the length of suspensions should be smaller than or at most equal to the "no development reported" period. Thus, project suspensions in the data are temporary in nature. As illustrated in Figure 3, a distinctive pattern emerges for the time period of the three types of project status: namely suspensions, failures and no development reported.

The number of months from start to final termination of a failed project is considerably larger than the maximum number of months for which a project can retain the status of "no development reported." Since the duration of a project suspension is smaller than or at the most equal to the maximum number of months for which a project can be labeled as "no development reported," from the comparison in Figure 3, one can conclude that the duration of project suspensions is much shorter than the life span of a failed project.

In addition, a failure may be dressed up as a suspension when firms with higher failure rates intentionally send false signals (Johnstone and Grafen, 1993). It is also necessary to have a better understanding of the degree to which there is an overlap between suspensions and failures. To probe this possibility, the researchers conducted a logistic regression, using project failure rates (i.e., the ratio of the total number of ceased drug development initiatives to the total number of all the drug development initiatives) in a focal firm to predict the likelihood of project suspensions while controlling for the other control variables included in Table 5. The results indicate that project failure rates do not predict project suspensions, suggesting that firms with higher failure rates would not be more likely to intentionally report failures as suspensions.

Beyond the analyses addressing the above questions, a number of other analyses were conducted. First was a test for potential selection bias, because entrepreneurial firms' valuations may be affected by unobserved factors that also influence entrepreneurial firms' intentions to form alliances, causing an endogeneity problem. Therefore a conventional Heckman two-stage approach was performed. In the first stage the tendency of forming alliances with partner firms was regressed on firm size, age, past performance, $\mathrm{R} \& \mathrm{D}$ expenditure, and failure rate. It was assumed that entrepreneurial firms with a higher failure rate and fewer resources were under greater pressure to form alliances with large firms to access external resources (Eisenhardt and Schoonhoven, 1996). The test suggested that selection was not an issue for this study's sample.

Second, previous research suggests that organizations require a certain amount of experiences of failure before they can extract and effectively apply knowledge from others' failures. Those with relatively little direct failure experience may misapply knowledge from their own successes and others' failures. Therefore the potential nonlinear relationship of the interaction effects was tested in an effort to identify the ideal failure rate (Barczak, 2014). These models suffered from potential multicolinearity (VIF $>10$ ) as a result of the simultaneous inclusion of the higher-order variables as both main effects and interaction effects. Such potential multicollinearity may produce misleading results since it artificially inflates the p-values of the individual effects (Greene, 2002). Further tests of the potential nonlinear relationship of project suspensions led to similar issues. 
Third was a check for any potential effects associated with the timing of alliance announcements over the industry life cycle. During the sample period, 1996-2003, the biopharmaceutical industry gained significantly in commercial and technological maturity. To account for this potential bias, calendar year dummies were included in each of the models. The substantive results remained unchanged.

Fourth, alternative alliance dummies were used as the reference group in the interaction terms, the main results remained unchanged.

Finally, a finer-grained categorization of the signaling environment capturing every stage of the NPD process was considered. However, there were missing data for some of the stages, which decreased the sample size, while these analyses required five additional variables as main effects, and $5 \times 2=10$ interaction effects. The results were consistent with the current analysis, but the models lacked degrees of freedom and hence are not reported here.

\section{Discussion}

\section{Main Results}

In many industries, including the pharmaceutical (Evans and Varaiya, 2003), telecommunications (Buganza, Dell'Era, and Verganti, 2009), software (Ethiraj, Kale, Krishnan, and Singh, 2009), and electronics ones (Terwiesch, Loch, and Niederkofler, 1998), entrepreneurial firms often enter into co-development alliances in pursuit of commercial innovations with large firms and other organizations. In these industries, failures and setbacks are an integral aspect of the NPD process. This article focused on the pharmaceutical industry, in which only 1 out of 5000 drug candidates reaches market launch (Evans and Varaiya, 2003) and only 20\% of drugs that make it to the market generate a financial return in excess of their cost of capital (Vernon, Golec, and DiMasi, 2010). Hence, research into the impact of prior project failures on the performance of subsequent NPD endeavors and how to improve this performance is critically important. Thus far, there has been limited research in this area. This is because failures are generally hidden both internally and from external parties as companies and individuals do not wish to admit them publicly nor take responsibility for them (Montoya-Weiss and Calantone, 1994; Smith-Doerr, Manev, and Rizova, 2004). Managers therefore speak asymmetrically about successes and failures. Only recently have scholars started to investigate how NPD failures affect firm performance and why some firms are affected by them differently than others (De Carolis et al., 2009; Girotra et al., 2007; Sarkar and De Jong, 2006; Urbig et al., 2013). This line of research, however, does not say much about project suspensions, either theoretically or empirically (Cooper and Edgett, 2012).

In regulated NPD environments where regulators proactively test the efficacy of an innovation and halt the development of innovations that are dangerous, both NPD project suspensions and failures can be observed. As argued in this article, project suspensions and failures are both indicative of a firm's inability to carry out a project to successful completion, but suspensions are distinct from failures in that, unlike failed projects, suspended ones (a) pass screening criteria and offer good investment potential and (b) can be reactivated once critical resource and timing issues have been resolved, for example when an alliance partner brings in the required expertise and financing.

Past innovation research has provided mixed findings regarding the relationship between project suspensions and failures and value creation. It has been argued that project suspensions in NPD may cause delays to the market, yet suspensions may also improve new product quality and the chances of success later on (McNally et al., 2011). Similarly, project failure may both improve and impede value creation. On the positive side, experience of failure has been shown to aid in organizational transformation (McNamara and BadenFuller, 1999), improve a firm's adaptability to environmental changes, and develop organizational reliability (Carmeli and Schaubroeck, 2008). Failure experience may also improve the outcomes of subsequent exploratory R\&D (Su and McNamara, 2012). However, prior failures are associated with rising operational costs (Baum and Dahlin, 2007) and are viewed negatively by peers (Edmondson, 2011). Therefore, more research into failure in innovation is needed (Barczak, 2014), in particular to understand its main and contingent effects on subsequent value creation.

To address this need, this article used signaling theory to delineate the positive effects of prior suspended projects and the negative effects of prior project failures on value creation by new co-development alliances. The findings provide new insights into the value of abandoned or shelved ideas and projects by shifting the focus away from temporal structuring mechanisms internal to a firm (Garud, Gehman, and Kumaraswamy, 2011; Lokshin et al., 2011; Orlikowski and Yates, 2002) and onto external mechanisms such as co-development alliances. The positive effect of 
project suspensions suggests that these may provide an opportunity for NPD teams to reflect on, articulate, and codify lessons learned from project experiences, and hence to improve future NPD project management (Shepherd, Patzelt, Williams, and Warnecke, 2014) and portfolio management; the latter has been rated as the weakest area of NPD (Cooper and Kleinschmidt, 1995; Kester et al., 2014).

In this study, the researchers further considered the contingent effect of suspended projects and failures by differentiating between alliances formed at different stages of the NPD process, namely exploration, moderate-scale exploitation, and large-scale exploitation. A particularly interesting finding is the contingent effect whereby exploration stages of the drug development process provide a positive context that enhances the positive impact of prior project suspensions and limits the negative impact of prior project failures on the value which investors attach to new co-development alliances. In contrast, moderate-scale exploitation stages of the drug development process provide a negative context. This has important implications for both theory and practice.

\section{Theoretical Implications}

Regarding theory, the findings demonstrate the effect of the signaling context on developing new drugs and products more broadly (Connelly et al., 2011; Lester et al., 2006) and suggest that signaling effects are contingent not only on how far a product is in its development process but also on an individual's (in this case, an investor's) perceptions. This adds to the prior co-development literature, which has considered alliances that combine complementary resources as a value-creation mechanism without taking the contingencies of the NPD process into account (Alvarez and Barney, 2001; Gulati et al., 2009; Yang et al., 2014). The insights deriving from construal theory indicate that the perceived value of prior and current projects-suspended, failed, and new codevelopment alliances-depends on the time (and psychological) distance from expected outcomes, such as new product launch. The further away a project is in time, the more individuals focus on the desirability of outcomes rather than their actual probability, and the more optimistic they become in their evaluations of these projects (Trope and Liberman, 2003). This creates a distorting effect, whereby exploration projects are viewed more positively than moderate-scale exploitation projects, even though considering the actual odds of success the opposite should be expected. Hence, future research may consider cognitive and psychological factors when analyzing the meaning and impact of signals (cf. Ozcan and Overby, 2008), but also when studying suboptimal NPD decisions that may hinder learning and decrease performance.

\section{Managerial Implications}

Considering the high failure rate in NPD and the lack of prior research on the different setbacks which may occur, the results of this study offer managerial insights for NPD management practice, in particular for managers of high-technology firms. This study's results will help them to better anticipate and understand the financial consequences of prior NPD project suspensions and failures. By understanding the differential impacts of suspensions and failures, managers can better analyze and assess past setbacks and failures and raise awareness about companies' suspension and failure profiles in accordance with setback types, and how value can best be generated in alliances. The findings on the positive influence of prior NPD project suspensions may suggest that proactively managing the tasks of portfolio management, including de-prioritizing existing projects while allocating and re-allocating resources to active projects (Cooper et al., 1998, 2001; Griffin, 1997), can send out positive signals to investors that the firm has good potential resources and a sound management ability to create better value in NPD alliances. The findings from this research therefore help to shed light on the effective mechanisms for tolerating setbacks, and creating or preserving value in innovation (Barczak, 2014).

Furthermore, the results suggest that exploration alliances add more to the positive value created by suspensions (or do more to counter the damage caused by failures) than moderate-scale exploitation alliances. In light of this particular finding, managers should be aware that signaling suspensions and failures to investors can influence their expectations and consequently impact shareholder value in the case of NPD alliance announcement. In particular, exploratory alliances seem to be an attractive stage at which to create or preserve value. Furthermore, the high failure rate in NPD suggests the need for firms to develop a culture that tolerates a process of developing innovations without certainty of outcomes, patience in the face of mounting losses, and willingness to accept failure (Tellis, 2012). For those firms planning to build a culture of tolerance toward failure, entering co-development alliances may be more desirable at exploratory stages than later on. 
In fact, exploration alliances can be conduits for organizational learning and co-creation of knowledge by partners where each party attempts to identify, transfer, and absorb part or all of the counterpart's valuable knowledge assets (Lubatkin, Florin, and Lane, 2001). Clarity about these effects can help managers to create and manage collaborations by addressing the conditions under which firms can create and preserve value in alliances (Fang, Lee, and Yang, 2015; Gulati et al., 2009; Merchant and Schendel, 2000). Importantly, of course, managers must also consider whether such signaling measures that preserve firm value in the short run can lead to success in the long run. In particular, they need to be aware of the potential psychological and cognitive factors that may lead to NPD screening and investment decisions that are more optimistic than rational, as such effects may apply equally to both investors and decision makers. It would be interesting for future research to investigate such effects.

\section{Limitations and Future Research}

Like all studies, the present one has limitations that in turn provide opportunities for future research. First, this article examined different types of setback from the perspective of the NPD process. Other types of setback and the impact of the heterogeneity of failure experience should be looked at in future studies (Haunschild and Sullivan, 2002). For example, future research could look into the types of NPD failure in incremental innovations and radical innovations. In addition, research might look at other types of failure during NPD, such as process failure (Shepherd et al., 2009) and strategic failure (Lant and Montgomery, 1987).

Second, this study focused only on biopharmaceutical companies, and thus on a single high-technology industry. While this sampling technique rules out methodological threats such as potential confounding effects (Zheng, Liu, and George, 2010), it raises the question of generalizability to a larger population. Caution must be exercised when transferring findings from a single industry to others, for example to an industry with shorter NPD cycles. It is hoped that future research will test whether this study's findings are robust in settings other than the biopharmaceutical industry.

Third, due to data limitations, this research could not find out what the ideal failure rate may be for the firms. Detailed data on project suspensions and failures at each and every stage of NPD may be helpful in this regard.

Fourth, the event study method used in this study has its limitations, such as the inability to include private firms.
Finally, this study provides only a snapshot of investors' reactions to how alliance events are affected by project suspensions and failures of firms; a longterm view may provide additional valuable insights (Sood and Tellis, 2009).

\section{References}

Ahuja, G., C. M. Lampert, and V. Tandon. 2008. Moving beyond Schumpeter: Management research on the determinants of technological innovation. The Academy of Management Annals 2 (1): 1-98.

Aiken, L. S., and S. G. West. 1991. Multiple regression: Testing and interpreting interactions. Newbury Park, CA: Sage Publications.

Akdeniz, M. B., R. J. Calantone, and C. M. Voorhees. 2014. Signaling quality: An examination of the effects of marketing-and nonmarketing-controlled signals on perceptions of automotive brand quality. Journal of Product Innovation Management 31 (4): 728-43.

Aldrich, H. E., and C. M. Fiol. 1994. Fools rush in? The institutional context of industry creation. Academy of Management Review 19 (4): 645-70.

Alvarez, S. A., and J. B. Barney. 2001. How entrepreneurial firms can benefit from alliances with large partners. Academy of Management Executive 15 (1): 139-48.

Anand, B. N., and T. Khanna. 2000. Do firms learn to create value? The case of alliances. Strategic Management Journal 21: 295-317.

Barczak, G. 2014. From the editor: JPIM research priorities. Journal of Product Innovation Management 31 (4): 640-41.

Barczak, G., A. Griffin, and K. B. Kahn. 2009. Perspective: Trends and drivers of success in NPD practices: Results of the 2003 PDMA best practices study. Journal of Product Innovation Management 26 (1): 3-23.

Barney, J. B. 1991. Firm resources and sustained competitive advantage. Journal of Management 17 (1): 99-120.

Baron, R. A. 2000. Psychological perspectives on entrepreneurship: Cognitive and social factors in an entrepreneur's success. Current Directions in Psychological Science 9 (1): 15-18.

Baum, J. A. C., and J. K. B. Dahlin. 2007. Aspiration performance and railroads' patterns of learning from train wrecks and crashes. Organization Science 18 (3): 368-85.

Baum, J. A. C., and B. S. Silverman. 2004. Picking winners or building them? Alliance, intellectual, and human capital as selection criteria in venture financing and performance of biotechnology startups. Journal of Business Venturing 19 (3): 411-36.

Blau, G. E., J. F. Pekny, V. A. Varma, and P. R. Bunch. 2004. Managing a portfolio of interdependent new product candidates in the pharmaceutical industry. Journal of Product Innovation Management 21 (4): 227-45.

Bourgeois, L. J. 1981. On the measurement of organizational slack. Academy of Management Review 6 (1): 29-39.

Boyd, D. E., R. K. Chandy, and M. Cunha Jr. 2010. When do chief marketing officers affect firm value? A customer power explanation. Journal of Marketing Research 47 (6): 1162-76.

Brown, J. S. 1997. Changing the game of corporate research: Learning to thrive in the fog of reality. In Technological innovation: Oversights and foresights, ed. R. Garud, P. R. Nayyar, and Z. Shapira, 95-110. New York: Cambridge University Press.

Brown, S. L., and K. M. Eisenhardt. 1995. Product development: Past research, present findings, and future directions. Academy of Management Review 20 (2): 343-78.

Buganza, T., C. Dell'Era, and R. Verganti. 2009. Exploring the relationships between product development and environmental turbulence: The case of mobile TLC services. Journal of Product Innovation Management 26 (3): 308-21. 
Busenitz, L. W., J. O. Fiet, and D. D. Moesel. 2005. Signaling in venture capitalist-new venture team funding decisions: Does it indicate long-term venture outcomes? Entrepreneurship Theory and Practice 29 (1): 1-12.

Carmeli, A., and J. Schaubroeck. 2008. Organizational crisis preparedness: The importance of learning from failure. Long Range Planning 41 (2): 177-96.

Certo, S. T., C. M. Daily, and D. R. Dalton. 2001. Signaling firm value through board structure: An investigation of initial public offerings. Entrepreneurship Theory and Practice 26 (2): 33-50.

Chandy, R., B. Hopstaken, O. Narasimhan, and J. Prabhu. 2006. From invention to innovation: Conversion ability in product development. Journal of Marketing Research 43 (3): 494-508.

Chang, S.-C., and S.-S. Chen. 2002. The wealth effect of domestic joint ventures: Evidence from Taiwan. Journal of Business Finance \& Accounting 29 (1/2): 201-22.

Chatterjee, S., M. H. Lubatkin, and W. S. Schulze. 1999. Toward a strategic theory of risk premium: Moving beyond CAPM. Academy of Management Review 24 (3): 556-567.

Chen, M. J., and D. C. Hambrick. 1995. Speed, stealth, and selective attack: How small firms differ from large firms in competitive behavior. Academy of Management Journal 38 (2): 453-82.

Cheng, J. L. C., and I. F. Kesner. 1997. Organizational slack and response to environmental shifts: The impact of resource allocation patterns. Journal of Management 23 (1): 1-18.

Cohen, B. D., and T. J. Dean. 2005. Information asymmetry and investor valuation of IPOs: Top management team legitimacy as a capital market signal. Strategic Management Journal 26 (7): 683-90.

Cohen, W. M., and D. A. Levinthal. 1990. Absorptive capacity: A new perspective on learning and innovation. Administrative Science Quarterly 35 (1): 128-52.

Connelly, B. L., S. T. Certo, R. D. Ireland, and C. R. Reutzel. 2011 Signaling theory: A review and assessment. Journal of Management 37 (1): 39-67.

Cooper, R. G. 1990. Stage-gate systems: A new tool for managing new products. Business Horizons 33 (3): 44-54.

Cooper, L. P. 2003. A research agenda to reduce risk in new product development through knowledge management: A practitioner perspective. Journal of Engineering and Technology Management 20 (1-2): 117-40.

Cooper, R. G. 2008. Perspective: The Stage Gate ${ }^{\circledR}$ idea to launch process-Update, what's new, and NexGen systems. Journal of Product Innovation Management 25 (3): 213-32.

Cooper, R. G., and S. J. Edgett. 2012. Best practices in the idea-tolaunch process and its governance. Research-Technology Management 55 (2): 43-54.

Cooper, R. G., S. J. Edgett, and E. J. Kleinshmidt. 1998. Portfolio management for new products. New York: Perseus Books.

Cooper, R. G., S. J. Edgett, and E. J. Kleinschmidt. 1999. New product portfolio management: Practices and performance. Journal of Product Innovation Management 16 (4): 333-51.

Cooper, R. G., S. J. Edgett, and E. J. Kleinschmidt. 2002. Optimizing the stage-gate process: What best-ractice companies do. ResearchTechnology Management 45 (5): 21-27.

Cooper, R. G., and E. J. Kleinschmidt. 1990. New product success factors: A comparison of "kills" versus successes and failures. $R \& D$ Management 20 (1): 47-63.

Das, S., and P. K. Sen, and S. Sengupta. 1998. Impact of strategic alliances on firm valuation. Academy of Management Journal 41 (1): 27-41.

De Carolis, D. M., Y. Yang, D. L. Deeds, and E. Nelling. 2009. Weathering the storm: The benefit of resources to high-technology ventures navigating adverse events. Strategic Entrepreneurship Journal 3 (2): 147-60.
Deeds, D. L., and C. W. Hill. 1996. Strategic alliances and the rate of new product development: An empirical study of entrepreneurial biotechnology firms. Journal of Business Venturing 11 (1): 41-55.

DiMasi, J. A., R. W. Hansen, and H. G. Grabowski. 2003. The price of innovation: New estimates of drug development costs. Journal of Health Economics 22 (2): 151-85.

Dosi, G. 1982. Technological paradigms and technological trajectories: A suggested interpretation of the determination and directions of technical change. Research Policy 11 (2): 147-62.

Dosi, G. 1988. Sources, procedures, and microeconomic effects of innovation. Journal of Economic Literature 26(3): 1120-71.

Edmondson, A. 2011. Strategies for learning from failure. Harvard Business Review 89 (4): 48-55.

Eisenhardt, K. M., and C. B. Schoonhoven. 1996. Resource-based view of strategic alliance formation: Strategic and social effects in entrepreneurial firms. Organization Science 7 (2): 136-50.

Emden, Z., R. J. Calantone, and C. Droge. 2006. Collaborating for new product development: Selecting the partner with maximum potential to create value. Journal of Product Innovation Management 23 (4): 330-41.

Ethiraj, S. K., P. Kale, M. S. Krishnan, and J. V. Singh. 2009. Where do capabilities come from and how do they matter? A study in the software services industry. Strategic Management Journal 26 (1): 25-45.

Evans, A. G., and N. P. Varaiya. 2003. Assessment of a biotech market opportunity. Entrepreneurship Theory and Practice 28 (1): 87-105.

Fang, E. 2008. Customer participation and the trade-off between new product innovativeness and speed to market. Journal of Marketing 72 (July): 90-104.

Fang, E., J. Lee, and Z. Yang. 2015. The timing of codevelopment alliances in new product development processes: Returns for upstream and downstream partners. Journal of Marketing 79 (1): 64-82.

FDA. 1999. From test tube to patient: Improving health through human drugs. Washington, DC: U.S. Government Printing Office.

Fleming, L., and O. Sorenson, 2001. Technology as a complex adaptive system: Evidence from patent data. Research Policy 30 (7): 1019-39.

Garud, R., J. Gehman, and A. Kumaraswamy. 2011. Complexity arrangements for sustained innovation: Lessons from 3M corporation. Organization Studies 32 (6): 737-67.

Garud, R., P. Tuertscher, and A. H. Van de Ven. 2013. Perspectives on innovation processes. The Academy of Management Annals 7 (1): 775-819.

George, G., S. A. Zahra, and D. R. Wood, Jr. 2002. The effects of business-university alliances on innovative output and financial performance: A study of publicly traded biotechnology companies. Journal of Business Venturing 17 (6): 577-609.

Girotra, K., C. Terwiesch, and K. T. Ulrich. 2007. Valuing R\&D projects in a portfolio: Evidence from the pharmaceutical industry. Management Science 53 (9): 1452-66.

Grant, R. M., and C. Baden-Fuller. 2004. A knowledge accessing theory of strategic alliances. Journal of Management Studies 41 (1): 61-84.

Greene, W. H. 2002. Econometric analysis (5th ed.). Upper Saddle River, NJ: Prentice-Hall.

Griffin, A. 1997. PDMA research on new product development practices: Updating trends and benchmarking best practices. Journal of Product Innovation Management 14 (6): 429-58.

Gulati, R., and M. C. Higgins. 2003. Which ties matter when? The contingent effects of interorganizational partnerships on IPO success. Strategic Management Journal 24 (2): 127-44.

Gulati, R., D. Lavie, and H. Singh. 2009. The nature of partnering experience and the gains from alliances. Strategic Management Journal 30 (11): 1213-33

Gulati, R., and L. O. Wang. 2003. Size of the pie and share of the pie: Implications of structural embeddedness for value creation and 
value appropriation in joint ventures. Research in the Sociology of Organizations 20: 209-42.

Haunschild, P. R., and B. N. Sullivan. 2002. Learning from complexity: Effects of prior accidents and incidents on airlines' learning. Administrative Science Quarterly 47 (4): 609-43.

Heide, J. B., and G. John. 1990. Alliances in industrial purchasing: The determinants of joint action in buyer-supplier relationships. Journal of Marketing Research 27 (February): 24-36.

Helfat, C. E., and R. S. Raubitschek. 2000. Product sequencing: Coevolution of knowledge, capabilities and products. Strategic Management Journal 21 (10/11): 961-79.

Henard, D. H., and D. M. Szymanski. 2001. Why some new products are more successful than others. Journal of Marketing Research 38 (3): 362-75.

Himmelmann, A., and D. Schiereck. 2009. R\&D progress and stock return — Evidence from the pharmaceutical and biotech industry. Paper presented at the CFF Research Conference, Vallendar, Germany.

Hitt, M. A., M. T. Dacin, E. Levitas, J Arregle, and A. Borza. 2000. Partner selection in emerging and developed market contexts: Resource-based organizational learning perspectives. Academy of Management Journal 43 (3): 449-67.

Hoang, H., and F. T. Rothaermel. 2005. The effect of general and partner-specific alliance experience on joint R\&D project performance. Academy of Management Journal 48 (2): 332-45.

Hoenig, D., and J. Henkel. 2015. Quality signals? The role of patents, alliances, and team experience in venture capital financing. Research Policy 44 (5): 1049-64.

Holmqvist, M. 2003. A dynamic model of intra-and interorganizational learning. Organization Studies 24 (1): 95-123.

Hu, Y., P. McNamara, and D. McLoughlin. 2015. Outbound open innovation in bio-pharmaceutical out-licensing. Technovation 35 (January): 46-58.

Ilmola, L., and O. Kuusi. 2006. Filters of weak signals hinder foresight: Monitoring weak signals efficiently in corporate decision-making. Futures 38 (8): 908-24.

Janney, J. J., and T. B. Folta. 2003. Signaling through private equity placements and its impact on the valuation of biotechnology firms. Journal of Business Venturing 18 (3): 361-80.

Johnstone, R. A., and A. Grafen. 1993. Dishonesty and the handicap principle. Animal Behaviour 46 (4): 759-64.

Katila, R., and G. Ahuja. 2002. Something old, something new: A longitudinal study of search behavior and new product introduction. Academy of Management Journal 45 (6): 1183-94

Katila, R., J. D. Rosenberger, and K. M. Eisenhardt. 2008. Swimming with sharks: Technology ventures, defense mechanisms and corporate relationships. Administrative Science Quarterly 53 (2): 295-332.

Kellogg, D., and J. M. Charnes. 2000. Real-options valuation for a biotechnology company. Financial Analysts Journal 56 (3): 76-84.

Kelley, D. J., and M. P. Rice. 2002. Advantage beyond founding: The strategic use of technologies. Journal of Business Venturing 17 (1): 41-57.

Kester, L., E. J. Hultink, and A. Griffin. 2014. An empirical investigation of the antecedents and outcomes of NPD portfolio success. Journal of Product Innovation Management 31 (6): 1199-1213.

Kirmani, A., and A. R. Rao. 2000. No pain, no gain: A critical review of the literature on signaling unobservable product quality. Journal of Marketing 64 (2): 66-79.

Lant, T. K., and D. B. Montgomery. 1987. Learning from strategic success and failure. Journal of Business Research 15 (6): 503-17.

Lee, J. 2011. The alignment of contract terms for knowledge-creating and knowledge-appropriating relationship portfolios. Journal of Marketing 75 (July): 110-27.

Lee, R. P., and Q. Chen. 2009. The immediate impact of new product introductions on stock price: The role of firm resources and size. Journal of Product Innovation Management 26 (1): 97-107.
Lee, I., and S. B. Wyatt. 1990. The effects of international joint ventures on shareholder wealth. Financial Review 25 (4): 641-49.

Lester, R. H., S. T. Certo, C. M. Dalton, D. R. Dalton, and A. A. Cannella. 2006. Initial public offering investor valuations: An examination of top management team prestige and environmental uncertainty. Journal of Small Business Management 44 (1): 1-26.

Levitas, E., and M. A. McFadyen. 2009. Managing liquidity in researchintensive firms: Signaling and cash flow effects of patents and alliance activities. Strategic Management Journal 30 (6): 659-78.

Liberman, N., and Y. Trope. 1998. The role of feasibility and desirability considerations in near and distant future decisions: A test of temporal construal theory. Journal of Personality and Social Psychology 75 (1): 5-18.

Lokshin, B., J. Hagedoorn, and W. Letterie. 2011. The bumpy road of technological partnerships: Understanding causes and consequences of partnership mal-functioning. Research Policy 40 (2): 297-308.

Lubatkin, M., J. Florin, and P. Lane. 2001. Learning together and apart: A model of reciprocal interfirm learning. Human Relations 54 (10): $1353-82$.

Makhija, M. V., and U. Ganesh. 1997. The relationship between control and partner learning in learning-related joint ventures. Organization Science 8 (5): 508-27.

March, J. G. 1991. Exploration and exploitation in organizational learning. Organization Science 2 (1): 1-87.

McConnell, J. J., and T. J. Nantell. 1985. Corporate combinations and common stock returns: The case of joint ventures. Journal of Finance 40 (2): 519-36.

McNally, R. C., B. Akdeniz, and R. J. Calantone. 2011. New product development processes and new product profitability: The mediating role of speed to market and product quality. Journal of Product Innovation Management 28 (S1): 63-77.

McNamara, P., and C. Baden-Fuller, 1999. Lessons from the Celltech case: Balancing knowledge exploration and exploitation in organizational renewal. British Journal of Management 10 (4): 291-307.

McWilliams, A., and D. Siegel. 1997. Event studies in management research: Theoretical and empirical issues. Academy of Management Journal 40 (3): 626-57.

Merchant, H., and D. Schendel. 2000. How do international joint ventures create shareholder value. Strategic Management Journal 21 (7): 723-37.

Mitchell, T. R., L. Thompson, E. Peterson, and R. Cronc. 1997. Temporal adjustments in the evaluation of events: The "rosy view." Journal of Experimental Social Psychology 33 (4): 421-48.

Montoya-Weiss, M. M., and R. Calantone. 1994. Determinants of new product performance: A review and metaanalysis. Journal of Product and Innovation Management 11 (5): 397-417.

Moran, M. 2003. Cost of bringing new drugs to market rising rapidly. Psychiatric News 38 (15): 25.

Nohria, N., and R. Gulati. 1996. Is slack good or bad for innovation? Academy of Management Journal 39 (5): 1245-64.

Öncüler, A. 2010. How do we manage an uncertain future? Ambiguity today is not ambiguity tomorrow. In The irrational economist: Making decisions in a dangerous world, ed. E. Michel-Kerjan and P. Slovic, 107-15. New York: Public Affairs.

Orlikowski, W. J., and J. Yates. 2002. It's about time: Temporal structuring in organizations. Organization Science 13 (6): 684-700.

Ortiz-Molina, H. 2006. Top management incentives and the pricing of corporate public debt. Journal of Financial and Quantitative Analysis 41 (2): $317-40$

Ozcan, S., and M. L. Overby. 2008. A cognitive model of stock market reactions to multi-firm alliance announcements. Strategic Organization 6 (4): 435-69.

Park, N. K. 2004. A guide to using event study methods in multicountry settings. Strategic Management Journal 25 (7): 655-68. 
Park, N. K., and J. M. Mezias. 2005. Before and after the technology sector crash: The effect of environmental munificence on stock market response to alliances of e-commerce firms. Strategic Management Journal 26 (11): 987-1107.

PhRMA. 2010. Pharmaceutical industry profile 2010. Washington, DC: Pharmaceutical Research and Manufacturers of America.

Pisano, G. P. 1990. The R\&D boundaries of the firm: An empirical analysis. Administrative Science Quarterly 35 (1): 153-76.

Porter, M. E. 1998. Cluster and the new economics of competition. Harvard Business Review 76 (6): 77-90.

Rasmussen, B. 2010. Innovation and commercialization in the biopharmaceutical sector: Creating and capturing value. London: Edward Elgar.

Rao, A. R., Q. Lu, and R. Ruekert. 1999. Signaling unobservable product quality through a brand ally. Journal of Marketing Research 36 (2): 258-68.

Rao, R. S., R. K. Chandy, and J. C. Prabhu. 2008. The fruits of legitimacy: Why some new ventures gain more from innovation than others. Journal of Marketing 72 (4): 58-75.

Reuer, J. J., and M. P. Koza. 2000. Asymmetric information and joint venture performance: Theory and evidence for domestic and international joint ventures. Strategic Management Journal 21 (1): 81-88.

Robertson, T. S., J. Eliashberg, and T. Rymon. 1995. New product announcement signals and incumbent reactions. Journal of Marketing 59 (July): 1-15.

Rothaermel, F. T. 2002. Technological discontinuities and interfirm cooperation: What determines a startup's attractiveness as alliance partner? IEEE Transactions on Engineering Management 49 (4): 388-97.

Rothaermel, F. T., and D. L. Deeds. 2004. Exploration and exploitation alliances in biotechnology: A system of new product development Strategic Management Journal 25 (3): 201-21.

Rothaermel, F. T., and D. L. Deeds. 2006. Alliance type, alliance experience and alliance management capability in high-technology ventures. Journal of Business Venturing 21 (4): 429-60.

Sampson, R. C. 2005. Experience effects and collaborative returns in R\&D alliances. Strategic Management Journal 26: 1009-1031.

Sanders, W. G., and S. Boivie. 2004. Sorting things out: Valuation of new firms in uncertain markets. Strategic Management Journal 25 (2): 167-86.

Sarkar, S. K., and P. J. De Jong. 2006. Market response to FDA announcements. Quarterly Review of Economics \& Finance 46 (4): 586-97.

Schilling, M. A. 1998. Technological lockout: An integrative model of the economic and strategic factors driving technology success and failure. Academy of Management Review 23 (2): 267-84

Shane, S., and T. Stuart. 2002. Organizational endowments and the performance of university start-ups. Management Science 48 (1): 154-70.

Sharma, A., and N. Lacey, 2004. Linking product development outcomes to market valuation of the firm: The case of the US pharmaceutical industry. Journal of Product Innovation Management 21 (5): 297-308.

Shepherd, D. A. 2003. Learning from business failure: Propositions of grief recovery for the self-employed. Academy of Management Review 28 (2): 318-28.

Shepherd, D. A., and M. S. Cardon. 2009. Negative emotional reactions to project failure and the self-compassion to learn from the experience. Journal of Management Studies 46 (6): 923-49.

Shepherd, D. A., J. G. Calantone, and D. F. Kuratko. 2009. Project failure from corporate entrepreneurship: Managing the grief process. Journal of Business Venturing 24 (6): 588-600.

Shepherd, D. A., H. Patzelt, T. A. Williams, and D. Warnecke. 2014 How does project termination impact project team members? Rapid termination, "creeping death," and learning from failure. Journal of Management Studies 51 (4): 513-546.

Smith-Doerr, L., I. M. Manev, and P. Rizova. 2004. The meaning of success: Network position and the social construction of project out- comes in an R\&D lab. Journal of Engineering and Technology Management 21 (1): 51-81.

Sood, A, and G. J. Tellis, 2009. Do innovations really pay off? Total stock market returns to innovation. Marketing Science 28 (3): 442-56.

Spence, M. 1973. Job market signaling. Quarterly Journal of Economics 87 (3): 355-74.

Spence, M. 2002. Signaling in retrospect and the informational structure of markets. American Economic Review 92 (3): 434-59.

StataCorp. 2007. Stata statistical software: Release 10.0 (10 ed.). College Station, TX: StataCorp LP.

Stuart, T. E. 2000. Interorganizational alliances and the performance of firms: A study of growth and innovation rates in high technology industry. Strategic Management Journal 21 (8): 791-811.

Stuart, T. E., H. Hoang, and R. Hybel. 1999. Interorganizational endorsements and the performance of entrepreneurial ventures. Administrative Science Quarterly 44 (2): 315-50.

Su, P., and P. McNamara. 2012. Exploration and exploitation within and across intra-organisational domains and their reactions to firmlevel failure. Technology Analysis and Strategic Management 24 (2): 129-49.

Swaminathan, V., and C. Moorman. 2009. Marketing alliances, firm networks, and firm value creation. Journal of Marketing 73 (September): $52-69$.

Tellis, G. J. 2012. Unrelenting innovation: How to create a culture for market dominance. San Francisco, CA: John Wiley \& Sons.

Terwiesch, C., C. Loch, and M. Niederkofler. 1998. When product development performance makes a difference: A statistical analysis in the electronics industry. Journal of Product Innovation Management 15 (1): 3-15.

Trope, Y., and N. Liberman. 2003. Temporal construal. Psychological Review 110 (3): 403-21.

Urbig, D., R. Bürger, H. Patzelt, and L. Schweizer. 2013. Investor reactions to new product development failures: The moderating role of product development stage. Journal of Management 39 (4): 9851015.

Van de Ven, A. H., D. Polley, R. Garud, and S. Venkataraman. 1999. The innovation journey. New York: Oxford University Press.

Vernon, J., J. Golec, and J. DiMasi. 2010. Drug development costs when financial risk is measured using the Fama-French three-factor model. Health Economics Letters 19 (8): 1002-5.

von Hippel, E. 1978. Successful industrial products from customer ideas. The Journal of Marketing 42 (1): 39-49.

Wernerfelt, B. 1984. A resource-based view of the firm. Strategic Management Journal 5 (2): 171-80.

Wheelwright, S. C., and K. B. Clark. 1992. Revolutionizing product development: Quantum leaps in speed, efficiency, and quality. New York: The Free Press.

Wuyts, S., S. Dutta, and S. Stremersch. 2004. Portfolios of interfirm agreements in technology-intensive markets: Consequences for innovation and profitability. Journal of Marketing 68 (April): 88-100.

Yamakawa, Y., H. Yang, and Z. Lin. 2011. Exploration versus exploitation in alliance portfolio: Performance implications of organizational, strategic, and environmental fit. Research Policy 40 (2): 287-96.

Yang, H., Y. Zheng, and X. Zhao. 2014. Exploration or exploitation? Small firms' alliance strategies with large firms. Strategic Management Journal 35 (1): 146-57.

Zheng, Y., J. Liu, and G. George. 2010. The dynamic impact of innovative capability and inter-firm network on firm valuation: A longitudinal study of biotechnology start-ups. Journal of Business Venturing 25 (6): 593-609. 